Article

\title{
Design and Synthesis of Thiazolo[5,4-f]quinazolines as DYRK1A Inhibitors, Part I
}

\author{
Alicia Foucourt ${ }^{1}$, Damien Hédou ${ }^{1}$, Carole Dubouilh-Benard ${ }^{1}$, Laurent Désiré ${ }^{2}$, \\ Anne-Sophie Casagrande ${ }^{2}$, Bertrand Leblond ${ }^{2}$, Nadège Loäec ${ }^{3,4}$, Laurent Meijer ${ }^{4}$ and \\ Thierry Besson 1,*
}

1 Normandie Univ, Laboratoire C.O.B.R.A., UMR 6014 and FR 3038; Univ Rouen; INSA de Rouen; CNRS, Bâtiment I.R.C.O.F. rue Tesnière, Mont-Saint-Aignan F-76821, France;

E-Mails: foucourtalicia@aol.com (A.F.); damien.hedou@etu.univ-rouen.fr (D.H.); carole.dubouilh@univ-rouen.fr (C.D.-B.)

2 Diaxonhit, 65 boulevard Masséna, Paris F-75013, France;

E-Mails: laurent.desire@diaxonhit.com (L.D.); anne-sophie.casagrande@diaxonhit.com (A.-S.C.); bertrandleblond@hotmail.com (B.L.)

3 Protein Phosphorylation \& Human Disease group, CNRS, Station Biologique, Roscoff F-29680, France; E-Mail: loaec@sb-roscoff.fr

4 ManRos Therapeutics, Centre de Perharidy, Roscoff F-29680, France;

E-Mail: meijer@manros-therapeutics.com

* Author to whom correspondence should be addressed; E-Mail: thierry.besson@univ-rouen.fr; Tel.: +33-235-522-904; Fax: +33-235-522-962.

External Editor: Philippe Belmont

Received: 29 July 2014; in revised form: 19 September 2014 / Accepted: 22 September 2014 / Published: 29 September 2014

\begin{abstract}
The convenient synthesis of a library of novel 6,6,5-tricyclic thiazolo[5,4- $f$ ] quinazolines (forty molecules) was achieved mainly under microwave irradiation. Dimroth rearrangement and 4,5-dichloro-1,2,3,-dithiazolium chloride (Appel salt) chemistry were associated for the synthesis of a novel 6-aminobenzo[d]thiazole-2,7-dicarbonitrile (16) a versatile molecular platform for the synthesis of various bioactive derivatives. Kinase inhibition of the final compounds was evaluated on a panel of four Ser/Thr kinases (DYRK1A, CDK5, CK1 and GSK3) chosen for their strong implications in various regulation processes, especially Alzheimer's disease (AD). In view of the results of this preliminary screening, thiazolo[5,4-f]quinazoline scaffolds constitutes a promising source of
\end{abstract}


inspiration for the synthesis of novel bioactive molecules. Among the compounds of this novel chemolibrary, 7i, $8 \mathbf{i}$ and $9 \mathbf{i}$ inhibited DYRK1A with $\mathrm{IC}_{50}$ values ranging in the double-digit nanomolar range (40, 47 and $50 \mathrm{nM}$, respectively).

Keywords: thiazolo[5,4-f]quinazolines; kinases inhibitors; DYRK1A; GSK3 $\alpha / \beta$; microwave-assisted chemistry; Dimroth rearrangement; appel salt

\section{Introduction}

Kinases are one of the largest enzyme families of the genome. More than 500 kinases play an important role in the regulation of most cellular processes. These enzymes are involved in all major diseases, including cancer, neurodegenerative disorders and cardiovascular diseases [1-3]. Our research groups are mainly invested in the synthesis of C,N,S- or C,N,O-containing heterocyclic precursors of bioactive molecules able to modulate the activity of kinases in signal transduction [4-8].

In the course of our work based on microwave-assisted chemistry, we described ten years ago the multistep synthesis of the $8 H$-thiazolo[5,4-f]quinazolin-9-ones (A) [9,10]. Brief studies of their structure-activity relationships as dual CDK1/GSK-3 kinases inhibitors were described [7]. At that time, the inhibitory potency of the final products was evaluated and some products showed a micromolar range affinity against DYRK1A [11]. More recently, the synthesis and the kinase inhibitory potency of various benzo-, pyrido- and pyrazinothieno[3,2- $d$ ]pyrimidines derivatives (B), have been published. Kinase inhibition of the compounds was evaluated on Ser/Thr kinases (CDK5, GSK3, DYRK1A, CLK1 and CK1) selected for their strong implications in various human pathologies, especially in AD [3].

The overall pharmaceutical interest of all these compounds encouraged us to conceive new series of thiazolo[5,4-f]quinazolines substituted in position 4 of the pyrimidine ring by an aromatic amine and by carboximidamide groups in position 2 of the thiazole moiety (see general formula $\mathbf{C}$ in Scheme 1).

Scheme 1. Structures of previous molecules which inspired the current work.
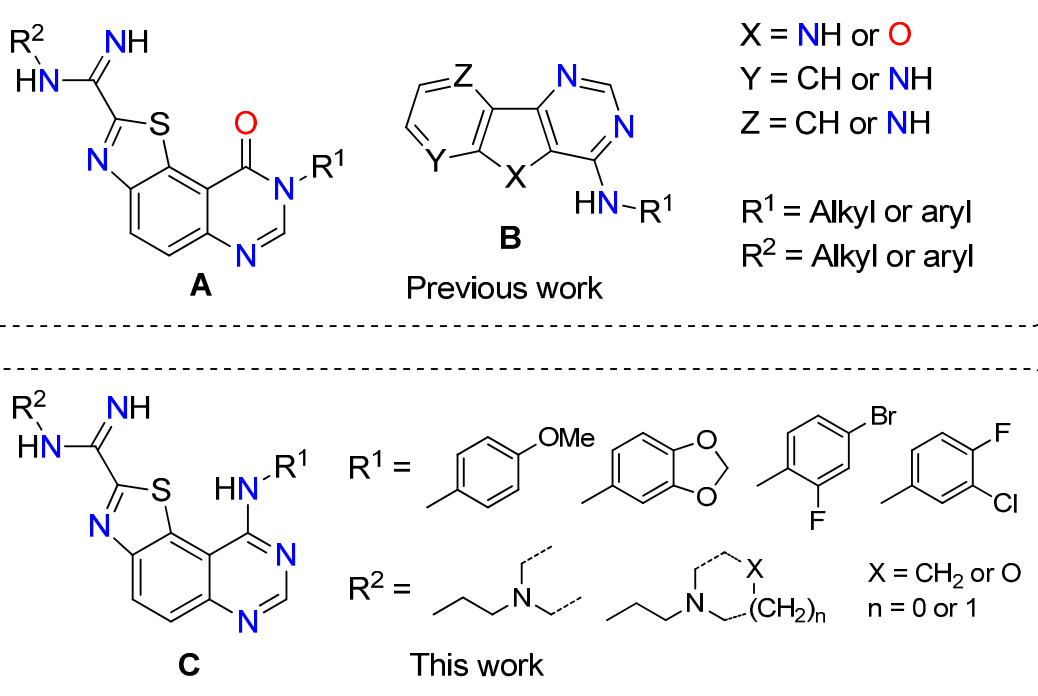
These compounds were conceived as 6,6,5-tricyclic homologues of the basic 4-aminoquinazoline pharmacophore which is present in approximately $80 \%$ of ATP-competitive kinase inhibitors that have received approval for the treatment of cancer [11]. The aromatic amine groups linked to the main thiazoloquinazoline structure were selected because of their frequent presence in drugs or drug candidates [11]. On the other side of the target molecules, the aliphatic chains of the carboximidamide groups were also chosen because of their frequent presence in many drugs.

This paper describes the development of a simple and reliable method that allows the preparation of a library of new thiazolo[5,4-f]quinazolines for which interesting kinase inhibitory activities were observed. The main part of the chemistry described in this paper was achieved under microwave irradiation as a continuation of our global strategy which consists to design adapted reactants and techniques offering operational, economic, and environmental benefits over conventional methods [12].

\section{Results and Discussion}

\subsection{Synthesis}

The target molecules we studied were thiazolo[5,4-f]quinazolines $(\mathbf{C})$ substituted in position 4 of the pyrimidine ring (which corresponds to position 9 of the tricyclic compound) by an aromatic amine. The retrosynthetic pathway depicted in Scheme 2 was directly inspired by our previous work on the synthesis of various thiazoloquinazoline isomers $[13,14]$ and on general access to pyrimidine-condensed heterocyclic compounds [15]. It suggested introducing the thiazole ring via a copper(I)-mediated cyclization of ortho-brominated $N$-arylimino-1,2,3-dithiazoles intermediates. The latter would be isolated after condensation of 4,5-dichloro-1,2,3-dithiazolium chloride (Appel salt) [16] with a key $N^{2}$-protected brominated aminoanthranilonitrile. The synthesis of the final pyrimidinic structures was envisioned via a microwave-assisted thermal-sensitive Dimroth rearrangement. [17] A nucleophilic attack of intermediate amidines by various aromatic amines would give the expected tricyclic compounds. This fast and convenient procedure was recently explored for the design of novel bioactive 4-anilinoquinazolines [4,5,17].

Scheme 2. General retrosynthetic pathways envisioned for this work.

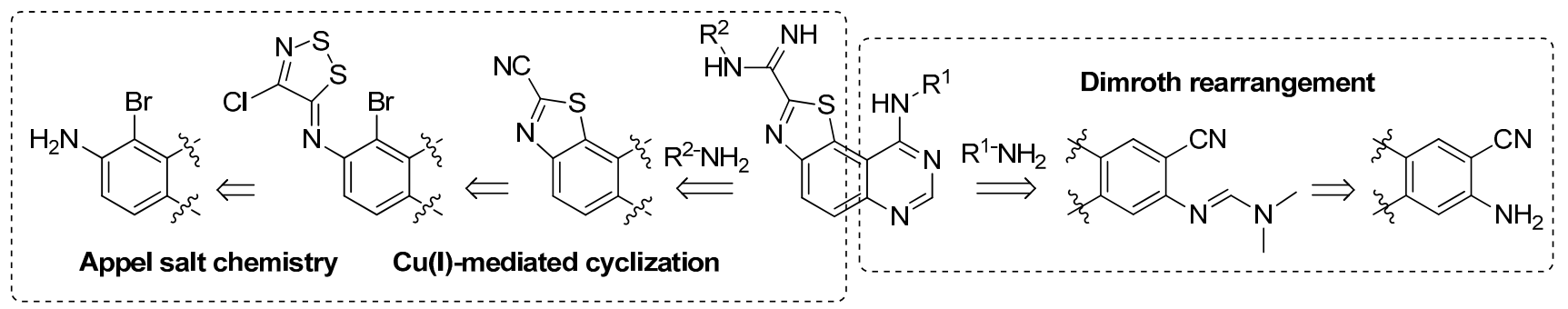

The synthetic route described in Scheme 2 was applied to the preparation of some of our target molecules. It started from 2-amino-5-nitroanthranilonitrile (1) which was treated for 15 min at $105{ }^{\circ} \mathrm{C}$ with $N, N$-dimethylformamide dimethyl acetal (DMFDMA) under microwave irradiation. The resulting $\mathrm{N}, \mathrm{N}$-dimethylformamidine $\mathbf{2}$ was heated with the appropriate aromatic amine in the presence of acetic acid at $118{ }^{\circ} \mathrm{C}$ for $20 \mathrm{~min}$. Compounds $\mathbf{3 a}-\mathbf{d}$ were then obtained in two steps in a good average yield of $85 \%$. 
In order to isolate the desired aryliminodithiazoles, 4-substituted-6-nitroquinazolinones 3a-c were first reduced into 6-amino derivatives $\mathbf{4 a - c}$ by transfer hydrogenation using ammonium formate in refluxing ethanol. Expectedly, in these conditions, the palladium-catalyzed reduction of the nitro group of intermediate $\mathbf{3 d}$ also provoked the protodehalogenation of the chloride atom of the 3-chloro-4-fluoroaniline moiety. This difficulty was circumvented when the reduction of 3d was achieved with iron and acetic acid in refluxing ethanol to give $\mathbf{4 d}$ in excellent yield (99\%).

Compounds 4a-d were treated with bromine in acetic acid to yield the ortho brominated imines $\mathbf{5 a - d .}$ In the case of $\mathbf{4 b}$, a polybrominated by-product $\mathbf{5 e}$ was obtained along with $\mathbf{5 b}$ whatever the conditions tested. Unfortunately both derivatives $\mathbf{5 b}$ and $\mathbf{5 e}$ were inseparable under convenient conditions. Another route consisting in preliminary bromination of the starting 5-nitroanthranilonitrile (1) was experimented. Unfortunately, whatever the bromination method, only 3-bromo-5-nitroanthranilonitrile (1b) was detected (see alternative route in Scheme 3).

Scheme 3. Synthetic routes experimented for the access to the target compounds (series 7-10).

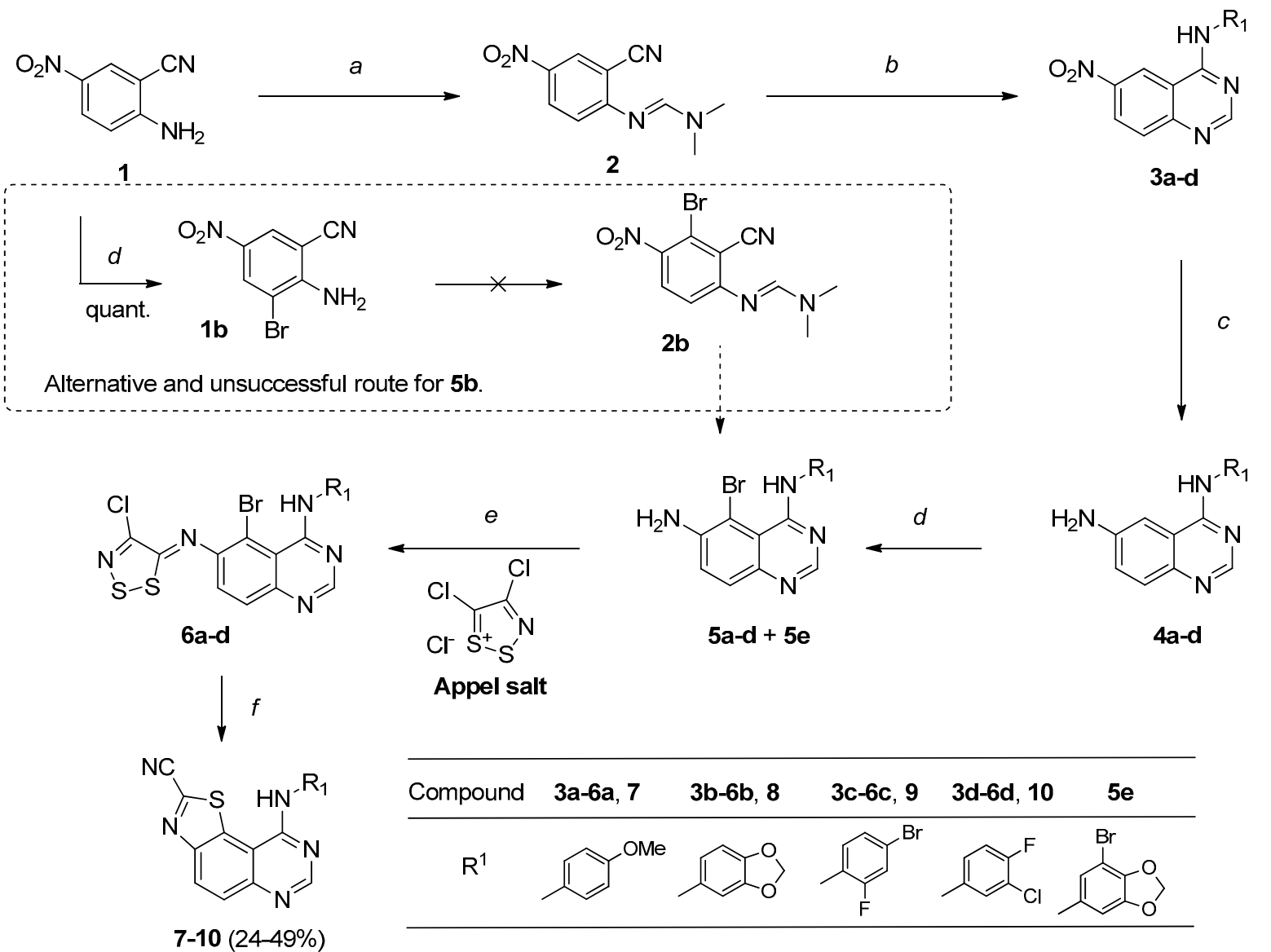

Reagents and conditions: (a) DMFDMA, DMF, $70{ }^{\circ} \mathrm{C}(\mu \mathrm{w}), 2 \mathrm{~min}, 94 \%$; (b) aniline (1.5 eq), AcOH, $118{ }^{\circ} \mathrm{C}$ ( $\mu \mathrm{w}), 2 \mathrm{~min}, 99 \%$ (3a)/45 min, 95\% (3b)/30 min, 70\% (3c)/10 min, 77\% (3d); (c) $\mathrm{HCO}_{2} \mathrm{NH}_{4}$, Pd.C, EtOH, $78{ }^{\circ} \mathrm{C}(\mu \mathrm{w}), 30 \mathrm{~min}, 99 \%$ (4a)/, 99\% (4b)/93\% (4c) or Fe, AcOH, EtOH, $78{ }^{\circ} \mathrm{C}(\mu \mathrm{w}), 5 \mathrm{~h}, 99 \%$ (4d); (d) $\mathrm{Br}_{2}$, $\mathrm{AcOH}, \mathrm{CH}_{2} \mathrm{Cl}_{2}$, r.t., 3.5 h; quant.; (e) Appel salt, Py. (2 eq), $\mathrm{CH}_{2} \mathrm{Cl}_{2}$, r.t., 4 h, $39 \%$ (6a) $/ 30 \%$ (6c) $/ 39 \%$ (6d); (f) CuI, Py., $130{ }^{\circ} \mathrm{C}(\mu \mathrm{w}), 20 \mathrm{~min}, 24 \%$ (7)/49\% (8)/30\% (9)/64\% (10).

Brominated intermediates 5a, 5c and 5d were condensed with 4,5-dichloro-1,2,3-dithiazolium chloride (Appel salt) in dichloromethane at room temperature and subsequent addition of pyridine led to 
the desired ortho-halogenated $\mathrm{N}$-aryliminodithiazoles $\mathbf{6 a}, \mathbf{6 c}$ and $\mathbf{6 d}$. The latter were converted into thiazolo[5,4-f]quinazoline-2-carbonitriles 7, 9 and $\mathbf{1 0}$ in copper(I)-catalyzed conditions $[14,16]$.

Despite its effectiveness, this synthesis presents some limitations. Each modification of the substituent in $N^{3}$ of the pyrimidine ring (e.g., 3a-d) generates three intermediates (e.g., 4a-d, 5a, c and $\mathbf{d}$ and $\mathbf{6 a}-\mathbf{d}$ in this study) for which synthetic and biological significance are not really established yet. The second drawback of this synthetic route lies in the reduction and bromination steps both of which require being adapted to the aromatic substituent of the intracyclic $N^{3}$-nitrogen atom. As an example, compound $\mathbf{5 b}$ was never isolated in analytically pure form and the synthesis of $\mathbf{8}$ via this intermediate was judged infeasible.

In order to avoid the limitations inherent in the first synthetic route and acquire an efficient and versatile route to various 9-anilinothiazolo[5,4-f]quinazolines, a rational multistep synthesis of a novel polyfunctionalized benzothiazole (see 16 in Scheme 4) was accomplished. This molecular system was designed as an efficient precursor of various target molecules.

Scheme 4. Multistep synthesis of polyfunctionalized benzothiazole 16.

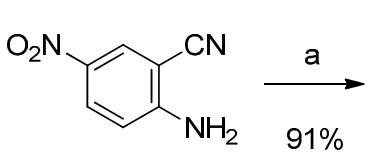

1

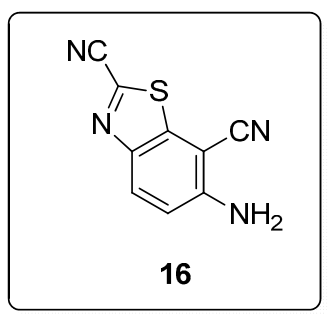<smiles>N#Cc1cc([N+](=O)[O-])ccc1NC(=O)OCc1ccccc1</smiles>

11

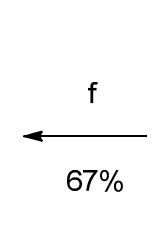

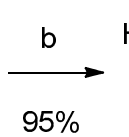

12

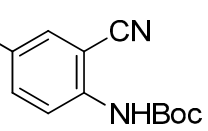

12

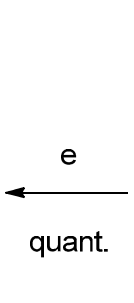

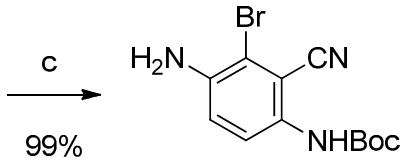

13

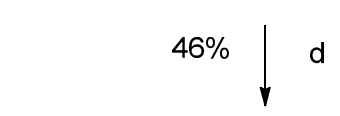

15

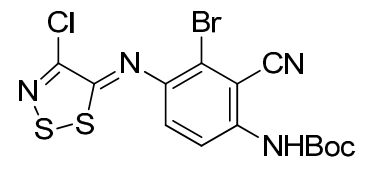

14

Reagents and conditions: (a) $\mathrm{Boc}_{2} \mathrm{O}$, DMAP, $\mathrm{Et}_{3} \mathrm{~N}, \mathrm{CH}_{2} \mathrm{Cl}_{2}$, r.t., 4 h; (b), $\mathrm{HCO}_{2} \mathrm{NH}_{4}$, Pd.C, $\mathrm{EtOH}, 78{ }^{\circ} \mathrm{C}(\mu \mathrm{w})$, 30 min; (c) $\mathrm{Br}_{2}, \mathrm{AcOH}, \mathrm{CH}_{2} \mathrm{Cl}_{2}$, r.t., 2.5 h; (d) Appel salt, Py. (2 eq), $\mathrm{CH}_{2} \mathrm{Cl}_{2}$, r.t., 4 h; (e) $\mathrm{AcOH}, 118^{\circ} \mathrm{C}(\mu \mathrm{w})$, 2 h; (f) CuI, Py., $130{ }^{\circ} \mathrm{C}(\mu \mathrm{w}), 20 \mathrm{~min}$.

Protection of 2-amino-5-nitrobenzonitrile (1) using di-tert-butyl dicarbonate was performed at room temperature in dichloromethane in the presence of triethylamine and 4-(dimethylamino)pyridine and provided tert-butyl (2-cyano-4-nitrophenyl)carbamate (11) in 91\% yield. Reduction of the nitro group of $\mathbf{1 1}$ was carried out as previously shown by palladium-catalyzed transfer hydrogenation in refluxing ethanol under microwave irradiation for $30 \mathrm{~min}$ and gave tert-butyl 4-amino-2-cyanophenylcarbamate 12 in high yield. Treatment of intermediate 12 with a solution of bromine in dichloromethane in acetic acid at room temperature provided tert-butyl 4-amino-3-bromo-2-cyanophenylcarbamate $\mathbf{1 3}$ in quantitative yield. The latter was reacted with Appel salt (4,5-dichloro-1,2,3-dithiazolium chloride) in dichloromethane at room temperature to afford tert-butyl-3-bromo-4-(4-chloro-5H-1,2,3-dithiazol-5ylideneamino)-2-cyanophenylcarbamate (14). $N$-Boc deprotection of 14 by acetic acid under microwave irradiation at $118{ }^{\circ} \mathrm{C}$ gave 6-amino-2-bromo-3-(4-chloro-5 $\mathrm{H}$-1,2,3-dithiazol-5-ylidene-amino)benzonitrile $\mathbf{1 5}$ in quantitative yield. Finally a copper-mediated cyclization of $\mathbf{1 5}$ was accomplished with $\mathrm{CuI}$ in pyridine under microwave irradiation at $130{ }^{\circ} \mathrm{C}$ for $20 \mathrm{~min}$ to give 6 -aminobenzo[ $d$ ] thiazole-2,7dicarbonitrile 16 in good yield (67\%). 
On a practical aspect, this synthetic sequence is easily upscalable and $10 \mathrm{~g}$ of 2-amino-5-nitrobenzonitrile (1) led to $2 \mathrm{~g}$ of $\mathbf{1 6}$ in an average 23\% yield. This new compound $\mathbf{1 6}$ can be considered as a molecular platform that can be employed in new areas of investigation and prove its utility for the synthesis of innovative molecular systems with potent biological applications. Indeed, the versatile carbonitrile function in position 2 of the thiazole ring may allow the synthesis of various amidine, imidazoline and imidate derivatives. On the other side the 2-aminobenzonitrile moiety offers a large panel of possibilities for extension of the aromatic structure with a heterocyclic core such as a pyrimidine (Scheme 5).

Scheme 5. Possible transformations of benzothiazole $\mathbf{1 6}$ as a versatile molecular platform.

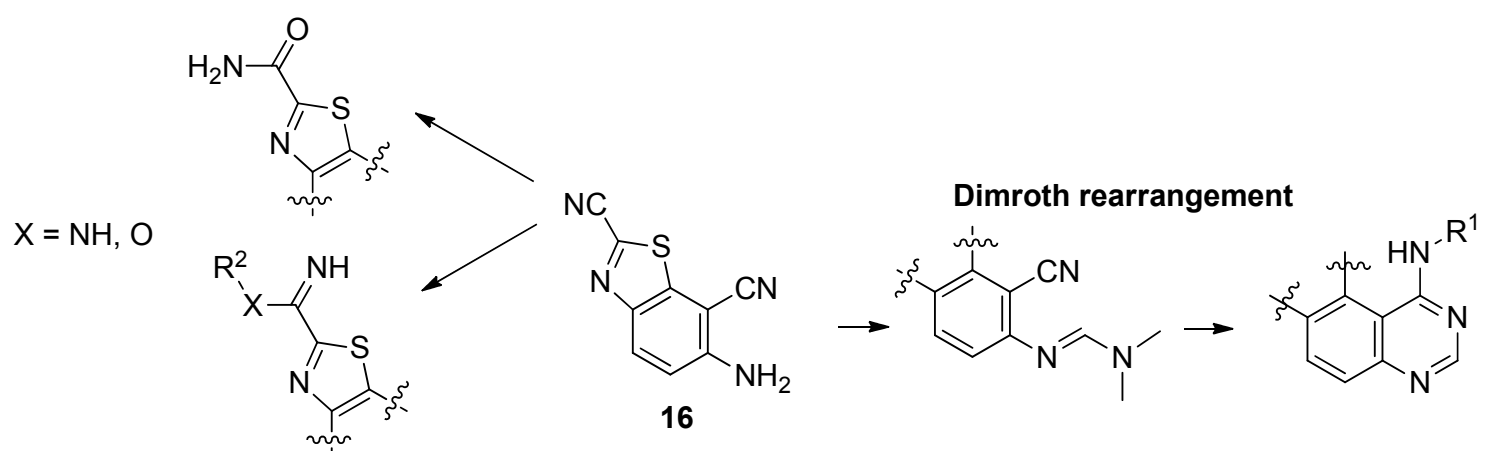

The synthesis of the target molecules was carried on by treatment of 16 with DMFDMA under microwave irradiation at $70{ }^{\circ} \mathrm{C}$ to give $(E)-N^{\prime}$-(2,7-dicyanobenzo[ $\left.d\right]$ thiazol-6-yl)- $N, N-$ dimethylformimidamide (17) in good yield (86\%). Cyclization of formimidamide 17 into thiazolo[5,4f quinazoline-2-carbonitriles was accomplished via thermal Dimroth rearrangement using 1.5 eq of the appropriate aniline in acetic acid under microwave irradiation at $118{ }^{\circ} \mathrm{C}$ for short times and gave compounds 7-10 in good yields (71\%-85\%). This method constitutes a versatile route to various compounds, especially $\mathbf{8}$ which was obtained in excellent yield (98\%).

In order to enhance the chemodiversity of the thiazolo[5,4-f]quinazolines studied, the reactivity of the aromatic carbonitriles $\mathbf{7 - 1 0}$ was tested against a panel of substituted amines (mainly alkylamines) inspired by our previous studies [4,5]. A new set of 27 novel carboximidamides $7 \mathbf{a}-\mathbf{g}, \mathbf{8 a}-\mathbf{f}, \mathbf{9 a}-\mathbf{g}$ and $\mathbf{1 0 a}-\mathbf{g}$ was prepared by stirring overnight at room temperature carbonitriles 7-10 with the appropriate amines (1.2 eq) in dry THF under argon. The chemical structures and yields obtained for the synthesis of the four prepared series $(\mathbf{7 a}-\mathbf{g}-\mathbf{1 0 a}-\mathbf{g})$ are shown in Table 1.

The key molecules $\mathbf{7 - 1 0}$ were also heated with sodium hydroxide (2.5 $\mathrm{N}$ in water) or with a solution of sodium methoxide in methanol to give respectively amides $\mathbf{7 h}-\mathbf{1 0 h}$ and methyl imidates $\mathbf{7 i}-\mathbf{1 0} \mathbf{i}$ in good to excellent yields (Scheme 6).

Note that microwave heating was mainly realized at atmospheric pressure in a controlled multimode cavity with a microwave power delivery system ranging from 0 to $1200 \mathrm{~W}$. Concerning the technical aspect, the choice of a reactor able to work at atmospheric pressure was guided by our previous experience in microwave-assisted heterocyclic synthesis, especially in the chemistry of quinazolines [6,9]. Open vessel microwave experiments have some advantages, such as the possibility of easier scale-up and the possibility to use current laboratory glassware. Our choice was also guided by a recent work describing the tendency of pressure to accumulate when a product as DMFDMA was heated in pressurized vials, 
especially under microwaves [18]. In most cases of our study, an irradiation of $800 \mathrm{~W}$ was enough to efficiently reach the programmed temperature. This parameter was mainly monitored via a contactless-infrared pyrometer which was calibrated in control experiments with a fiber-optic contact thermometer.

Scheme 6. Synthesis of thiazolo[5,4-f]quinazoline-2-carbonitriles $\mathbf{7 - 1 0}$ and their derivatives via transformation of the carbonitrile functions in carboxamidines (a-g), amides (h) or imidates (i).

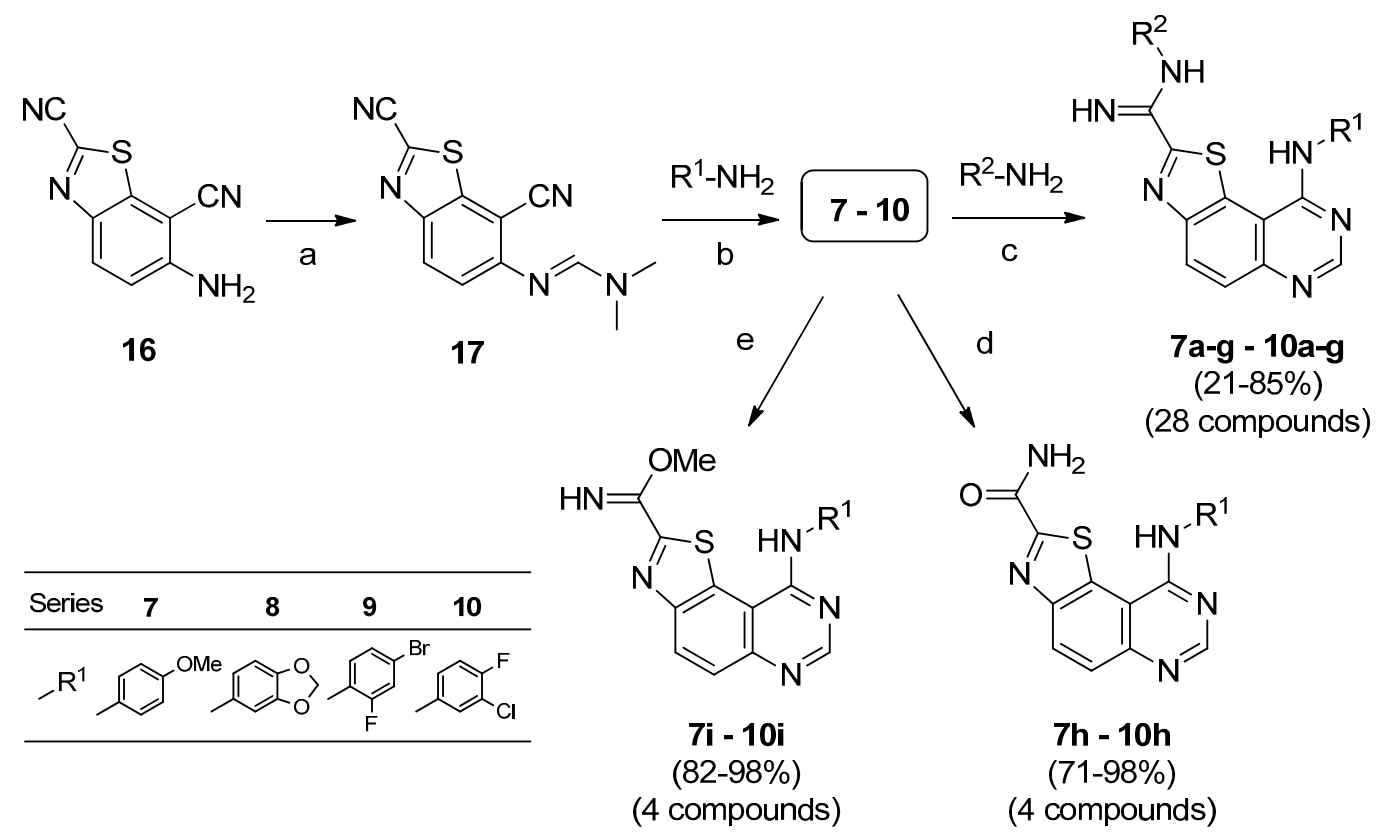

Reagents and conditions: (a) DMFDMA, DMF, $70{ }^{\circ} \mathrm{C}(\mu \mathrm{w}), 2 \mathrm{~min}, 86 \%$; (b) aniline (1.5 eq), $\mathrm{AcOH}, 118{ }^{\circ} \mathrm{C}$ ( $\mu \mathrm{w}$ ), $2 \mathrm{~min}, 99 \%$ (7)/45 $\mathrm{min}, 95 \%$ (8)/30 $\mathrm{min}, 70 \%$ (9)/10 $\mathrm{min}, 77 \%$ (10); (c) amines, THF, r.t., $12 \mathrm{~h}$, for yields see Table 1; (d) $\mathrm{NaOH}_{\mathrm{aq}}(2.5 \mathrm{~N})$, butanol, $117{ }^{\circ} \mathrm{C}(\mu \mathrm{w}), 30 \mathrm{~min}, 98 \%$ (7h)/91\% (8h)/71\% (9h)/98\% (10h); (e) $\mathrm{NaOMe}(0.5 \mathrm{M}$ in $\mathrm{MeOH}), \mathrm{MeOH}, 65{ }^{\circ} \mathrm{C}(\mu \mathrm{w}), 30 \mathrm{~min}, 82 \%$ (7i)/92\% (8i)/94\% (9i)/98\% (10i).

Table 1. Chemical structures and yields obtained for the synthesis of the four series $(\mathbf{7 a}-\mathbf{g}-\mathbf{1 0 a}-\mathbf{g})$.

\begin{tabular}{|c|c|c|c|c|c|c|c|}
\hline $\mathbf{R}_{1}$ & $\mathbf{R}_{\mathbf{2}}$ & Compound & Yield $^{a}(\%)$ & $\mathbf{R}_{1}$ & $\mathbf{R}_{\mathbf{2}}$ & Compound & Yield ${ }^{a}(\%)$ \\
\hline & & $7 a$ & 41 & & & 9a & 85 \\
\hline & & $7 b$ & 43 & & & $9 b$ & 72 \\
\hline & & $7 c$ & 47 & & & $9 c$ & 68 \\
\hline & & $7 d$ & 53 & & & 9d & 64 \\
\hline & & $7 e$ & 50 & & & $9 e$ & 86 \\
\hline & & $7 \mathrm{f}$ & 28 & & & 9f & 68 \\
\hline & $5=$ & $7 \mathrm{~g}$ & 67 & & & $9 \mathrm{~g}$ & 40 \\
\hline
\end{tabular}


Table 1. Cont.

\begin{tabular}{|c|c|c|c|c|c|c|c|}
\hline $\mathbf{R}_{1}$ & $\mathbf{R}_{2}$ & Compound & Yield $^{\text {a }}(\%)$ & $\mathbf{R}_{1}$ & $\mathbf{R}_{\mathbf{2}}$ & Compound & Yield a $(\%)$ \\
\hline & & $8 a$ & 41 & & & $10 a$ & 71 \\
\hline & & $8 b$ & 34 & & & $10 \mathrm{~b}$ & 82 \\
\hline & & $8 c$ & 48 & & & $10 \mathrm{c}$ & 69 \\
\hline & & $8 d$ & 30 & & & 10d & 50 \\
\hline & & $8 e$ & 66 & & & $10 \mathrm{e}$ & 50 \\
\hline & & $8 f$ & 21 & & & $10 \mathrm{f}$ & 69 \\
\hline & $s^{5}$ & $8 \mathrm{~g}$ & $-\mathrm{b}$ & & & $10 \mathrm{~g}$ & 43 \\
\hline
\end{tabular}

${ }^{\mathrm{a}}$ Isolated yield; ${ }^{\mathrm{b}}$ Not prepared.

\subsection{Biological Studies}

Compounds of series $7(7,7 \mathbf{a}-\mathbf{i})$, series $8(\mathbf{8}, \mathbf{8 a}-\mathbf{i})$, series $9(9,9 \mathbf{a}-\mathbf{i})$ and series $10(10,10 a-i)$

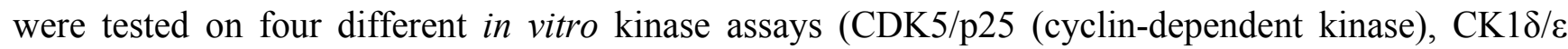
(casein kinase 1), GSK3 $\alpha / \beta($ Glycogen Synthase Kinase 3) and DYRK1A (dual-specificity, tyrosine phosphorylation regulated kinase) to evaluate their inhibition potency [19-23]. These four kinases are all involved in Alzheimer's disease (AD), a multi-kinase inhibitor able to target two or three of them could be quite desirable. This is linked to the fact that it is still not known whether any of these four kinases plays a more prominent role in Alzheimer's disease than the others and, consequently, which one should therefore preferably be targeted. In pathological situations such kinases are overexpressed and-activated, this fact justify the interest of multi-target-directed ligands (MTDLs) while complete inhibition is likely to be detrimental.

All compounds were first tested at a final concentration of $10 \mu \mathrm{M}$. Compounds showing less than $50 \%$ inhibition were considered as inactive ( $\mathrm{IC}_{50}>10 \mu \mathrm{M}$ ). Compounds displaying more than $50 \%$ inhibition at $10 \mu \mathrm{M}$ were next tested over a wide range of concentrations (usually from 0.01 to $10 \mu \mathrm{M}$ ), and $\mathrm{IC}_{50}$ values were determined from the dose-response curves (Sigma-Plot). Harmine is a $\beta$-carboline alkaloid known to be a potent inhibitor of DYRK1A [24]. Leucettine L41 is also a potent DYRK1A inhibitor derived from a marine natural product, Leucettamine B [25,26]. They were tested as positive controls and their IC50 values were compared with those obtained for the compounds under study.

Results given in Table 2 demonstrate that none of the thiazolo[5,4- $f$ quinazoline derivatives exhibited any inhibitory activity against CDK5/p25 and CK1. Precursors 7, 8, 9 and 10, were completely inactive against all four tested kinases $\left(\mathrm{IC}_{50}>10 \mu \mathrm{M}\right)$.

On a general aspect, compounds $\mathbf{a}-\mathbf{f}$ of series $\mathbf{7 , 9}$ and $\mathbf{1 0}$ were also judged inactive against DYRK1A, except for some compounds (8b-8e) of series $\mathbf{8}$ for which micromolar IC50 values were observed. Note that among the four families of tested molecules, all compounds of $\mathbf{a}-\mathbf{f}$ series were found relatively active (mainly in the micromolar range) against GSK3 $\alpha / \beta$. All these compounds were substituted with bulky aminoethyl groups on the carboximidamide function of the final structures. The large size of these 
groups appeared to influence the reactivity of the products against the four kinases tested, conferring them a relative selectivity for GSK $3 \alpha / \beta\left(1.10 \mu \mathrm{M}<\mathrm{IC}_{50}<7.00 \mu \mathrm{M}\right)$.

Table 2. Kinase inhibitory activity ${ }^{\mathrm{a}, \mathrm{b}, \mathrm{c}}$ of the four thiazolo[5,4-f]quinazoline series $(\mathbf{7 a}-\mathbf{i}-\mathbf{1 0 a}-\mathbf{i})$.

\begin{tabular}{cccccccccc}
\hline Compound & DYRK1A & CK1 & CDK5 & GSK3 & Compound & DYRK1A & CK1 & CDK5 & GSK3 \\
\hline $\mathbf{7}$ & $>10$ & $>10$ & $>10$ & $\geq 10$ & $\mathbf{9}$ & $>10$ & $>10$ & $>10$ & $>10$ \\
$\mathbf{7 a}$ & $>10$ & $>10$ & $>10$ & 1.10 & $\mathbf{9 a}$ & $>10$ & $>10$ & $>10$ & 1.8 \\
$\mathbf{7 b}$ & $>10$ & $>10$ & $>10$ & 2.50 & $\mathbf{9 b}$ & $>10$ & $>10$ & $>10$ & $\mathbf{0 . 5 3}$ \\
$\mathbf{7 c}$ & $>10$ & $>10$ & $>10$ & 2.00 & $\mathbf{9 c}$ & $>10$ & $>10$ & $>10$ & 2.20 \\
$\mathbf{7 d}$ & $>10$ & $>10$ & $>10$ & $>10$ & $\mathbf{9 d}$ & $>10$ & $>10$ & $>10$ & $\mathbf{0 . 9 5}$ \\
$\mathbf{7 e}$ & 4.00 & $>10$ & $>10$ & 1.30 & $\mathbf{9 e}$ & $>10$ & $>10$ & $>10$ & 2.10 \\
$\mathbf{7 f}$ & 8.00 & $>10$ & $>10$ & 2.00 & $\mathbf{9 f}$ & $>10$ & $>10$ & $>10$ & 1.80 \\
$\mathbf{7 g}$ & $\mathbf{0 . 7 0}$ & $>10$ & $>10$ & 1.10 & $\mathbf{9 g}$ & $\mathbf{0 . 2 7}$ & $>10$ & $>10$ & $\mathbf{0 . 6 0}$ \\
$\mathbf{7 h}$ & $\mathbf{0 . 5 0}$ & $>10$ & $>10$ & $\mathbf{0 . 3 0}$ & $\mathbf{9 h}$ & $\mathbf{0 . 6 7}$ & $>10$ & $>10$ & $\mathbf{0 . 1 3}$ \\
$\mathbf{7 i}$ & $\mathbf{0 . 0 4 0}$ & $>10$ & $>10$ & $\mathbf{0 . 2 0}$ & $\mathbf{9 i}$ & $\mathbf{0 . 0 5 0}$ & $>10$ & $>10$ & $\mathbf{0 . 1 6}$ \\
$\mathbf{8}$ & $>10$ & $>10$ & $>10$ & $\geq 10$ & $\mathbf{1 0}$ & $>10$ & $>10$ & $>10$ & $>10$ \\
$\mathbf{8 a}$ & 2.20 & $>10$ & $>10$ & $\mathbf{0 . 9 7}$ & $\mathbf{1 0 a}$ & $>10$ & $>10$ & $>10$ & 3.50 \\
$\mathbf{8 b}$ & 2.00 & $>10$ & $>10$ & 1.10 & $\mathbf{1 0 b}$ & $>10$ & $>10$ & $>10$ & 1.40 \\
$\mathbf{8 c}$ & 1.10 & $>10$ & $>10$ & $\mathbf{0 . 3 6}$ & $\mathbf{1 0 c}$ & $>10$ & $>10$ & $>10$ & 2.50 \\
$\mathbf{8 d}$ & 1.05 & $>10$ & $>10$ & $\mathbf{0 . 2 5}$ & $\mathbf{1 0 d}$ & $>10$ & $>10$ & $>10$ & 3.00 \\
$\mathbf{8 e}$ & 6.50 & $>10$ & $>10$ & $\mathbf{0 . 8 0}$ & $\mathbf{1 0 e}$ & $>10$ & $>10$ & $>10$ & 7.00 \\
$\mathbf{8 f}$ & $>10$ & $>10$ & $>10$ & 2.00 & $\mathbf{1 0 f}$ & $>10$ & $>10$ & $>10$ & $>10$ \\
$\mathbf{8 g}$ & $-{ }^{\mathrm{d}}$ & - & - & - & $\mathbf{1 0 g}$ & 6.50 & $>10$ & $>10$ & 7.20 \\
$\mathbf{8 h}$ & $\mathbf{0 . 8 0}$ & $>10$ & $>10$ & $\mathbf{0 . 7 7}$ & $\mathbf{1 0 h}$ & 1.60 & $>10$ & $>10$ & $\mathbf{0 . 6 6}$ \\
$\mathbf{8 i}$ & $\mathbf{0 . 0 4 7}$ & $>10$ & $>10$ & $\mathbf{0 . 6 6}$ & $\mathbf{1 0 i}$ & $\mathbf{0 . 2 5}$ & $>10$ & $>10$ & $\mathbf{0 . 6 9}$ \\
\hline
\end{tabular}

${ }^{\mathrm{a}} \mathrm{IC}_{50}$ values are reported in $\mu \mathrm{M}$. The most significant results are presented in bold; ${ }^{\mathrm{b}}$ Kinases activities were assayed in triplicate. Typically, the standard deviation of single data points was below $10 \%$; ${ }^{\mathrm{c}}$ Harmine $\left(\mathrm{IC}_{50}\right.$ in $\left.\mu \mathrm{M}\right)$ : DYRK1A: 0.029; CK1: 1.50; CDK5 and GSK3 $\alpha / \beta$ : > 10 [27]; Leucettine L41 (IC 50 in $\mu$ M): DYRK1A: 0.040; CK1: > 10; CDK5: $>10$ and GSK3 $\alpha / \beta$ : 0.040 [27]; ${ }^{\mathrm{d}}$ Not determined.

Among the compounds tested, the two most interesting series are $\mathbf{8}$ and $\mathbf{9}$ which showed submicromolar values against GSK3 $\alpha / \beta$. From this point of view, series $\mathbf{8}$ is really promising with micromolar range activities against DYRK1A $\left(6.5 \mu \mathrm{M}<\mathrm{IC}_{50}<1.05 \mu \mathrm{M}\right)$ and submicromolar IC 50 values against GSK $3 \alpha / \beta\left(0.25 \mu \mathrm{M}<\mathrm{IC}_{50}<0.97 \mu \mathrm{M}\right)$.

Undoubtedly, the most active molecules prepared in this study were series $\mathbf{g}-\mathbf{i}$ of the four family of thiazolo[5,4-f]quinazolines (7-10). The latter showed spectacular submicromolar activities against DYRK1A $\left(0.04 \mu \mathrm{M}<\mathrm{IC}_{50}<0.70 \mu \mathrm{M}\right)$ and GSK3 $\alpha / \beta$ kinases $\left(0.16 \mu \mathrm{M}<\mathrm{IC}_{50}<0.77 \mu \mathrm{M}\right)$ with a marked preference for the first one, respectively. The DYRK1A IC 50 values obtained for $\mathbf{7 i}, \mathbf{8 i}$ and $9 \mathbf{i}$ are situated in the double-digit nanomolar range (40, 47 and $50 \mathrm{nM}$, respectively) demonstrating that small-sized groups linked to the thiazole ring were able to induce a dramatic enhancement of the inhibitory activity against DYRK1A.

Taking into account these preliminary results, defining a specific role of the aromatic substituents of the amine located at position 4 of the pyrimidine ring remains challenging. Nevertheless, the presence of substituting groups on the aromatic moiety seemed to have a positive effect on the inhibitory activity of the studied compounds. Without being able to establish a general rule, the presence of substituents in 
positions 2 and 4 of the aromatic chain (series 9) has a rather beneficial effect compared to substituents in position 3 and 4 (series 8 and 10).

The most active thiazoloquinazolines were less potent and specific against DYRK1A (Table 2) compared to harmine and leucettine L41 [25-27] but constitute a promising source of inspiration for the synthesis of novel bioactive molecules. Our results confirm that the thiazolo[5,4-f]quinazoline scaffold has a great potential in the development of potent inhibitors of DYRK1A and GSK3 $\alpha / \beta$ kinases that are involved in many neurodegenerative diseases and cancers. Lead compounds $7 \mathbf{i}, \mathbf{8} \mathbf{i}$ and $9 \mathbf{i}$ presented in this paper allow us to consider further structure-activity relationships for the design of more efficient and selective inhibitors of these targeted kinases.

\section{Experimental Section}

\subsection{General Information}

All reactions were carried out under inert atmosphere of argon or nitrogen and monitored by thin-layer chromatography with silica gel 60 F254 pre-coated aluminum plates $(0.25 \mathrm{~mm})$. Visualization was performed with a UV light at 254 and $312 \mathrm{~nm}$. Purifications were carried out on an Armen Instrument Spot 2 Flash System equipped with a dual UV-Vis spectrophotometer (200-600 nm), a fraction collector (192 tubes), a dual piston pump ( 1 to $250 \mathrm{~mL} / \mathrm{min}, \mathrm{P}_{\max }=50 \mathrm{bar} / 725 \mathrm{psi}$ ) allowing quaternary gradients and an additional inlet for air purge. Samples can be injected in liquid or solid mode. Purification was edited and monitored on an integrated panel PC with a touch screen controlled by Armen Glider Flash v3.1d software [28]. Biotage SNAP flash chromatography cartridges (KP-Sil, normal phase, 10 to $340 \mathrm{~g}$ ) were used for the purification process. Melting points of solid compounds were measured on a WME Köfler hot-stage with a precision of $+/-2{ }^{\circ} \mathrm{C}$ and are uncorrected. IR spectra were recorded on a PerkinElmer Spectrum 100 Series FT-IR spectrometer. Liquids and solids were applied on the Single Reflection Attenuated Total Reflectance (ATR) Accessories. Absorption bands are given in $\mathrm{cm}^{-1}$.

${ }^{1} \mathrm{H} /{ }^{19} \mathrm{~F} /{ }^{13} \mathrm{C}$-NMR spectra were recorded on a Bruker DXP 300 spectrometer at 300,282 and $75 \mathrm{MHz}$ respectively. Abbreviations used for peak multiplicities are s: singlet, d: doublet, t: triplet, q: quadruplet and m: multiplet. Coupling constants $J$ are in $\mathrm{Hz}$ and chemical shifts are given in ppm and calibrated with DMSO- $d_{6}$ or $\mathrm{CDCl}_{3}$ (residual solvent signals). Mass spectra analysis was performed by the Mass Spectrometry Laboratory of the University of Rouen. Mass spectra (EI) were recorded with a Waters LCP 1 er XR spectrometer.

Dichloromethane was distilled from $\mathrm{CaH}_{2}$ under argon. NBS was recrystallized in water. Other reagents and solvents were used as provided by commercial suppliers.

Appel salt was prepared according to literature procedure [16] by addition of chloroacetonitrile ( 1 eq) to a solution of sulfur dichloride (5 eq) in dichloromethane $(50 \mathrm{~mL})$. Adogen ${ }^{\mathrm{TM}}$ (3-4 drops) was then added and the reaction was placed in a bowl of cold water. The mixture was left for $18 \mathrm{~h}$ without stirring under $\mathrm{CaCl}_{2}$ tube protection: The dark olive green solid was removed from the wall of the flask, filtered off under a blanket of argon, washed abundantly with dichloromethane and dried under vacuum for 2-3 h (average yield: $85 \%$ ): $\mathrm{mp} 172-174{ }^{\circ} \mathrm{C}$ (dec); IR (nujol) $\mathrm{cm}^{-1} 1707,1358 \mathrm{~s}, 1280 \mathrm{~s}, 1253,1083$, $917,828 \mathrm{~s}$, and 605 . 
Microwave experiments were conducted at atmospheric pressure in a commercial microwave reactors especially designed for synthetic chemistry. Time indicated in the various protocols is the time measured when the mixtures reached the programmed temperature after a ramp period of 2 min. RotoSYNTH'M (Milestone S.r.l. Italy) is a multimode cavity with a microwave power delivery system ranging from 0 to $1200 \mathrm{~W}$. Open vessel experiments were carried out in round bottom flask (from $25 \mathrm{~mL}$ to $4 \mathrm{~L}$ ) fitted with a reflux condenser. The temperature was monitored via a contact-less infrared pyrometer (IRT) and fiber-optic contact thermometer (FO). Temperature, pressure and power profiles were edited and monitored through the EASY-Control software provided by the manufacturer. Compounds $7 \mathbf{a}-\mathbf{i}, \mathbf{8 a}-\mathbf{i}$, 9a-i and 10a-i, 16 and $\mathbf{1 7}$ were described in a previous patent application [29]; to help readers, physicochemical data of these compounds are added in the following experimental part.

\subsection{Synthesis}

\subsubsection{Synthesis of Formamidine $\mathbf{2}$ and Amines $\mathbf{3 a}, \mathbf{3 c}$ and $\mathbf{3 d}$}

$N$-(2-Cyano-4-nitrophenyl)- $N, N$-dimethylformamidine (2), $N$-(4-methoxyphenyl)-6-nitro-quinazolin-4amine (3a), $N$-(4-bromo-2-fluorophenyl)-6-nitroquinazolin-4-amine (3c) and $N$-(3-chloro-4fluorophenyl)-6-nitroquinazolin-4-amine (3d) were prepared and characterized following the general procedure described in [6].

$N$-(Benzo[d][1,3]dioxol-5-yl)-6-nitroquinazolin-4-amine (3b). A mixture of $N^{\prime}$-(2-cyano-4nitrophenyl)- $N, N$-dimethylformamidine $(2,1.0 \mathrm{~g}, 4.58 \mathrm{mmol})$ and 3,4-(methylenedioxy)aniline $(0.63 \mathrm{~g}$, $4.58 \mathrm{mmol})$ in acetic acid $(5 \mathrm{~mL})$ was heated at $118{ }^{\circ} \mathrm{C}$ under microwaves $(600 \mathrm{~W})$. On completion (followed by TLC or GC-MS), the reaction was cooled to ambient temperature. The separated solid was filtered and washed with diethyl ether to obtain the expected compound $\mathbf{3 b}(1.08 \mathrm{~g}, 76 \%)$ as a brown solid; $\mathrm{mp}>260^{\circ} \mathrm{C}$. IR $\left(\mathrm{cm}^{-1}\right) v_{\max } 1581,1512,1490,1321,1245,1222,1188,1031,921,896,846,807$; ${ }^{1} \mathrm{H}-\mathrm{NMR}\left(\mathrm{DMSO}-d_{6}\right) \delta 10.3(\mathrm{~s}, 1 \mathrm{H}, \mathrm{NH}), 9.57(\mathrm{~d}, 1 \mathrm{H}, J=2.1 \mathrm{~Hz}), 8.64(\mathrm{~s}, 1 \mathrm{H}), 8.52\left(\mathrm{dd}, 1 \mathrm{H}, J_{1}=2.1 \mathrm{~Hz}\right.$, $\left.J_{2}=9.0 \mathrm{~Hz}\right), 7.88(\mathrm{~d}, 1 \mathrm{H}, J=9.0 \mathrm{~Hz}), 7.44(\mathrm{~s}, 1 \mathrm{H}), 7.18(\mathrm{~m}, 1 \mathrm{H}), 6.96(\mathrm{~d}, 1 \mathrm{H}, J=9.0 \mathrm{~Hz}), 5.75(\mathrm{~s}, 2 \mathrm{H})$; ${ }^{13} \mathrm{C}-\mathrm{NMR}\left(\mathrm{DMSO}-d_{6}\right) \delta 158.6,157.6,152.9,146.8,144.2,144.1,132.3,129.2,126.2,120.5,116.1$, 114.1, 107.6, 105.0, 101.2; HRMS calcd for $\mathrm{C}_{15} \mathrm{H}_{11} \mathrm{~N}_{4} \mathrm{O}_{4}[\mathrm{M}+\mathrm{H}]^{+}$311.0780, found 311.0794.

\subsubsection{Synthesis of Diamines $\mathbf{4 b}, \mathbf{4 c}$ and $\mathbf{4 d}$}

General procedure: a stirred mixture of $\mathbf{3 b}, \mathbf{3 c}$ and $\mathbf{3 d}$ ( $1 \mathrm{mmol})$, ammonium formate $(5 \mathrm{mmol})$ and a catalytic amount of $10 \%$ palladium charcoal in $20 \mathrm{~mL}$ of ethanol was heated at reflux $(600 \mathrm{~W})$ for $30 \mathrm{~min}$. The catalyst was removed by filtration through Celite and washed with ethanol. The resulting filtrate was evaporated under reduced pressure to give $\mathbf{4 b}, \mathbf{4 c}$ and $\mathbf{4 d}$.

$N^{4}$-(Benzo[d][1,3]dioxol-5-yl)quinazoline-4,6-diamine (4b). Prepared from 36 (quant. yield); brown solid; $\mathrm{mp}=112-114{ }^{\circ} \mathrm{C}$. IR $(\mathrm{KBr}) v_{\max } / \mathrm{cm}^{-1} 3339,2976,1619,1572,1530,1499,1448,1384,1343$, 1255, 1190, 1095, 1045, 932, 882, 823; ${ }^{1} \mathrm{H}-\mathrm{NMR}$ (DMSO-d6) $\delta 8.20(\mathrm{~s}, 1 \mathrm{H}), 7.51(\mathrm{dd}, 2 \mathrm{H}$, $\left.J_{1}=2.0 \mathrm{~Hz}, J_{2}=9.0 \mathrm{~Hz}\right), 7.32(\mathrm{~d}, 1 \mathrm{H}, J=2.0 \mathrm{~Hz}), 7.23-7.18(\mathrm{~m}, 2 \mathrm{H}), 6.91(\mathrm{~d}, 1 \mathrm{H}, J=9.0 \mathrm{~Hz}), 6.00(\mathrm{~s}$, $2 \mathrm{H}) ;{ }^{13} \mathrm{C}-\mathrm{NMR}$ (DMSO-d $) \delta 163.7,156.3,149.9,147.3,146.9,143.2,142.1,134.0,128.4,123.6,116.6$, 115.2, 107.8, 104.6, 101.1; HRMS calcd for $\mathrm{C}_{15} \mathrm{H}_{13} \mathrm{~N}_{4} \mathrm{O}_{2}[\mathrm{M}+\mathrm{H}]^{+}: 281.1039$, found 281.1033. 
$N^{4}$-(4-Bromo-2-fluorophenyl)quinazoline-4,6-diamine (4c). Prepared from 3c (yield: 93\%); brown solid; $\mathrm{mp}=216-218^{\circ} \mathrm{C} . \mathrm{IR}\left(\mathrm{cm}^{-1}\right) v_{\max } 3245,3067,1923,1614,1561,1533,1493,1424,1390,1335,1237$, 1206, 1070, 887, 846, 825; ${ }^{19} \mathrm{~F}-\mathrm{NMR}$ (DMSO- $d 6$ ) $\delta-115.6 ;{ }^{1} \mathrm{H}-\mathrm{NMR}$ (DMSO- $d 6$ ) $\delta 8.53(\mathrm{~s}, 1 \mathrm{H}), 7.72$ $(\mathrm{d}, 1 \mathrm{H}, J=9.9 \mathrm{~Hz}), 7.62(\mathrm{~d}, 1 \mathrm{H}, J=8.7 \mathrm{~Hz}), 7.52(\mathrm{~m}, 2 \mathrm{H}), 7.40-7.36(\mathrm{~m}, 2 \mathrm{H}) ;{ }^{13} \mathrm{C}-\mathrm{NMR}$ (DMSO- $\left.d 6\right) \delta$ $158.8,158.4,155.1,149.6,146.6,131.2,130.1,128.0,127.9,126.0,124.7,124.5,121.7,120.0,119.9$, 119.8, 119.5, 115.1, 101.4; HRMS calcd for $\mathrm{C}_{14} \mathrm{H}_{11} \mathrm{~N}_{4} \mathrm{BrF}[\mathrm{M}+\mathrm{H}]^{+}: 334.0151$, found 334.0158.

$N^{4}$-(3-Chloro-4-fluorophenyl)quinazoline-4,6-diamine (4d). Prepared from 3d (99\% yield); brown solid; $\mathrm{mp}=244-246^{\circ} \mathrm{C} . \mathrm{IR}\left(\mathrm{cm}^{-1}\right) v_{\max } 2501,1633,1614,1568,1503,1432,1373,1266,1214,888,871,794$;

${ }^{19} \mathrm{~F}-\mathrm{NMR}\left(\mathrm{DMSO}-d_{6}\right) \delta-123.9 ;{ }^{1} \mathrm{H}-\mathrm{NMR}$ (DMSO- $\left.d_{6}\right) \delta 9.48(\mathrm{~s}, 1 \mathrm{H}, \mathrm{NH}), 8.36(\mathrm{~s}, 1 \mathrm{H}), 8.21(\mathrm{dd}, 1 \mathrm{H}$, $\left.J_{1}=2.4 \mathrm{~Hz}, J_{2}=6.9 \mathrm{~Hz}\right), 7.85-7.80(\mathrm{~m}, 1 \mathrm{H}), 7.55(\mathrm{~d}, 1 \mathrm{H}, J=9.3 \mathrm{~Hz}), 7.41(\mathrm{t}, 1 \mathrm{H}$, $J=9.3 \mathrm{~Hz}$ ); 7.30-7.24 (m, 2H); ${ }^{13} \mathrm{C}-\mathrm{NMR}$ (DMSO- $d 6$ ) $\delta 155.7,154.5,151.3,149.5,147.5,142.6,137.4$, 137.3, 128.7, 123.8, 122.8, 121.8, 121.7, 118.8, 188.6, 116.7, 116.6, 116.3, 100.9; HRMS calcd for $\mathrm{C}_{14} \mathrm{H}_{11} \mathrm{~N} 4 \mathrm{ClF}[\mathrm{M}+\mathrm{H}]^{+}: 289.0656$, found 289.0663 .

\subsubsection{Synthesis of Brominated Diamines 5a, $\mathbf{5} \mathbf{c}$ and $\mathbf{5 d}$}

General procedure: a solution of bromine $(2.9 \mathrm{mmol})$ in dichloromethane $(3 \mathrm{~mL})$ was added dropwise, under an argon atmosphere, to a solution of amines $\mathbf{4 a}, \mathbf{4 c}$ and $\mathbf{4 d}(2.9 \mathrm{mmol})$ in acetic acid (34 $\mathrm{mL})$. After $3.5 \mathrm{~h}$ of stirring at room temperature, the solvent was removed in vacuo. Excess acetic acid was co-evaporated with heptane to afford the expected compounds $\mathbf{5 a}, \mathbf{5 c}$ and $\mathbf{5 d}$.

5-Bromo- $N^{4}$-(4-methoxyphenyl)quinazoline-4,6-diamine (5a). Prepared from 4a (quant. Yield), beige solid; $\mathrm{mp}>260^{\circ} \mathrm{C}$. IR $\left(\mathrm{cm}^{-1}\right) v_{\max } 3297,3106,3065,2950,2668,1607,1567,1510,1381,1356,1299$, 1229, 1168, 1073, 1024, 820, 802; ${ }^{1} \mathrm{H}-\mathrm{NMR}$ (DMSO-d6) $\delta 10.54$ (s, 1H, NH), $8.69(\mathrm{~s}, 1 \mathrm{H}), 7.71-7.68$ $(\mathrm{m}, 2 \mathrm{H}), 7.64(\mathrm{~d}, 2 \mathrm{H}, J=9.0 \mathrm{~Hz}), 7.03(\mathrm{~d}, 2 \mathrm{H}, J=9.0 \mathrm{~Hz}), 3.78(\mathrm{~s}, 3 \mathrm{H}) ;{ }^{13} \mathrm{C}-\mathrm{NMR}$ (DMSO-d 6$) \delta 157.7$, 157.1, 147.9, 145.9, 131.7, 129.3, 125.6, 125.2, 119.4, 114.1, 113.0, 96.3, 55.5; HRMS calcd for $\mathrm{C}_{15} \mathrm{H}_{14} \mathrm{~N}_{4} \mathrm{OBr}[\mathrm{M}+\mathrm{H}]^{+}:$345.0351, found 345.0367.

5-Bromo- $N^{4}$-(4-bromo-2-fluorophenyl)quinazoline-4,6-diamine (5c). Prepared from 4c (quant. Yield), yellow solid; $\mathrm{mp}>260^{\circ} \mathrm{C}$. IR $\left(\mathrm{cm}^{-1}\right) v_{\max } 3369,3334,3256,1619,1565,1514,1477,1432,1410,1390$, $1327,1262,1235,1179,1165,1100,1063,954,928,875,857,828,815 ;{ }^{19}$ F-NMR (DMSO-d6) $\delta-119.3$; ${ }^{1} \mathrm{H}-\mathrm{NMR}\left(\mathrm{DMSO}-d_{6}\right) \delta 8.46(\mathrm{~s}, 1 \mathrm{H}), 8.01(\mathrm{t}, 1 \mathrm{H}, J=9.0 \mathrm{~Hz}), 7.69-7.61(\mathrm{~m}, 2 \mathrm{H}), 7.53(\mathrm{~d}, 1 \mathrm{H}, J=9.0 \mathrm{~Hz})$, $7.47(\mathrm{~m}, 1 \mathrm{H}) ;{ }^{13} \mathrm{C}-\mathrm{NMR}$ (DMSO- $\left.d_{6}\right) \delta 156.3,155.9,152.9,147.0,137.3,127.5,126.8,124.9,123.5$, 118.9, 118.6, 117.5, 113.6, 94.9; HRMS calcd for $\mathrm{C}_{14} \mathrm{H}_{10} \mathrm{~N}_{4} \mathrm{Br}_{2} \mathrm{~F}[\mathrm{M}+\mathrm{H}]^{+}$: 410.9256, found 410.9243.

5-Bromo- $N^{4}$-(3-chloro-4-fluorophenyl)quinazoline-4,6-diamine (5d). Prepared from 4d (quant. Yield), orange solid; $\mathrm{mp}>260^{\circ} \mathrm{C}$. IR $\left(\mathrm{cm}^{-1}\right) v_{\max } 3464,3319,3286,3185,2736,1705,1626,1566,1519,1495$, 1425, 1384, 1360, 1329, 1302, 1267, 1214, 1159, 1136, 1054, 930, 872, 826; ${ }^{19} \mathrm{~F}-\mathrm{NMR}$ (DMSO-d6) $\delta-118.8 ;{ }^{1} \mathrm{H}-\mathrm{NMR}\left(\mathrm{DMSO}-d_{6}\right) \delta 10.51(\mathrm{~s}, 1 \mathrm{H}, \mathrm{NH}), 8.75(\mathrm{~s}, 1 \mathrm{H}), 8.04\left(\mathrm{dd}, 1 \mathrm{H}, J_{1}=2.4 \mathrm{~Hz}, J_{2}=6.9 \mathrm{~Hz}\right)$, 7.71-7.68 (m, 2H), $7.63(\mathrm{~d}, 1 \mathrm{H}, J=9.0 \mathrm{~Hz}), 7.55(\mathrm{t}, 1 \mathrm{H}, J=9.0 \mathrm{~Hz}) ;{ }^{13} \mathrm{C}-\mathrm{NMR}$ (DMSO-d6) $\delta 157.4$, $156.8,153.5,148.1,145.9,133.8,133.7,132.5,126.1,125.6,125.0,124.9,119.8,119.5,119.3,117.2$, 116.9, 113.3, 95.9; HRMS calcd for $\mathrm{C}_{14} \mathrm{H}_{10} \mathrm{~N}_{4} \mathrm{BrClF}[\mathrm{M}+\mathrm{H}]^{+}: 366.9761$, found 366.9770. 


\subsubsection{Synthesis of Imino-1,2,3-dithiazoles $\mathbf{6 a}, \mathbf{6 c}$ and $\mathbf{6 d}$}

General procedure: a suspension of the 5-bromoquinazoline $\mathbf{5 a}, \mathbf{5 c}$ and $\mathbf{5 d}$. (10 mmol), 4,5-dichloro-1,2,3-dithiazolium chloride $12(22 \mathrm{mmol})$ in dichloromethane $(50 \mathrm{~mL})$ was stirred at room temperature under an argon atmosphere. After $3 \mathrm{~h}$ of stirring at room temperature, pyridine (44 mmol) was added and the mixture was stirred again for $1 \mathrm{~h}$ at room temperature. Then the resulting solution was concentrated under reduced pressure. The obtained crude residue was purified by flash chromatography (DCM-EtOAc, 8:2) to afford the expected compounds $\mathbf{6 a}, \mathbf{6 c}$ and $\mathbf{6 d}$.

(Z)-5-Bromo- $N^{6}$-(4-chloro-5H-1,2,3-dithiazol-5-ylidene)- $N^{4}$-(4-methoxyphenyl)quinazoline-4,6-diamine

(6a). Prepared from 5a (yield: 39\%), brown solid; $\mathrm{mp}>260^{\circ} \mathrm{C}$. IR $\left(\mathrm{cm}^{-1}\right) v_{\max } 3239,1607,1567,1504$, 1440, 1377, 1303, 1249, 1172, 1027, 830; ${ }^{1} \mathrm{H}-\mathrm{NMR}$ (DMSO-d6) $\delta 10.93$ (s, 1H, NH), 8.96 (s, 1H), 7.95-7.85 (m, 2H), $7.66(\mathrm{~d}, 2 \mathrm{H}, J=9.0 \mathrm{~Hz}), 7.07$ (d, 2H, $J=9.0 \mathrm{~Hz}), 3.79$ (s, 3H); HRMS calcd for $\mathrm{C}_{17} \mathrm{H}_{12} \mathrm{~N}_{5} \mathrm{OSS}_{2} \mathrm{BrCl}\left(\mathrm{M}+\mathrm{H}^{+}\right): 479.9355$, found 479.9362 .

(Z)-5-Bromo- $N^{4}$-(4-bromo-2-fluorophenyl)- $N^{6}$-(4-chloro-5H-1,2,3-dithiazol-5-ylidene) quinazoline-4,6diamine (6c). Prepared from 5c (yield: 30\%), yellow solid; $\mathrm{mp}=198-200{ }^{\circ} \mathrm{C}$. IR $\left(\mathrm{cm}^{-1}\right) v_{\max } 3336,3086$, 1704, 1621, 1610, 1593, 1530, 1489, 1478, 1407, 1389, 1314, 1237, 1180, 1146, 1109, 945, 921, 859, 852, 835, 818, 810; ${ }^{19} \mathrm{~F}-\mathrm{NMR}$ (DMSO- $\left.d_{6}\right) \delta-118.3 ;{ }^{1} \mathrm{H}-\mathrm{NMR}$ (DMSO- $\left.d_{6}\right) \delta 9.78(\mathrm{~s}, 1 \mathrm{H}, \mathrm{NH}), 8.57$ (s, 1H), $7.98(\mathrm{~m}, 1 \mathrm{H}), 7.91(\mathrm{~d}, 1 \mathrm{H}, J=9.0 \mathrm{~Hz}), 7.76(\mathrm{~d}, 1 \mathrm{H}, J=9.0 \mathrm{~Hz}), 7.70(\mathrm{~m}, 1 \mathrm{H}), 7.49(\mathrm{~m}, 1 \mathrm{H})$; HRMS calcd for $\mathrm{C}_{16} \mathrm{H}_{8} \mathrm{~N}_{5} \mathrm{~S}_{2} \mathrm{Br}_{2} \mathrm{ClF}[\mathrm{M}+\mathrm{H}]^{+}: 545.8260$, found 585.8273 .

(Z)-5-Bromo- $N^{4}$-(3-chloro-4-fluorophenyl)- $N^{6}$-(4-chloro-5H-1,2,3-dithiazol-5-ylidene) quinazoline-4,6diamine (6d). Prepared from 5d (yield: 39\%), orange solid; $\mathrm{mp}=218-220{ }^{\circ} \mathrm{C}$. IR $\left(\mathrm{cm}^{-1}\right) v_{\max } 3353$, 2980, 1571, 1534, 1492, 1414, 1383, 1337, 1261, 1207, 1153, 1054, 960, 921, 869, 803; ${ }^{19} \mathrm{~F}-\mathrm{NMR}$ $\left(\mathrm{DMSO}-d_{6}\right) \delta-118.1 ;{ }^{1} \mathrm{H}-\mathrm{NMR}\left(\mathrm{DMSO}-d_{6}\right) \delta 9.90(\mathrm{~s}, 1 \mathrm{H}, \mathrm{NH}), 8.62(\mathrm{~s}, 1 \mathrm{H}), 8.08\left(\mathrm{dd}, 1 \mathrm{H}, J_{1}=2.4 \mathrm{~Hz}\right.$, $\left.J_{2}=6.9 \mathrm{~Hz}\right), 7.93(\mathrm{~d}, 1 \mathrm{H}, J=9.0 \mathrm{~Hz}), 7.77(\mathrm{~d}, 1 \mathrm{H}, J=9.0 \mathrm{~Hz}), 7.71-7.66(\mathrm{~m}, 1 \mathrm{H}), 7.46(\mathrm{t}, 1 \mathrm{H}$, $J=9.0 \mathrm{~Hz}$ ); HRMS calcd for $\mathrm{C}_{16} \mathrm{H}_{8} \mathrm{~N}_{5} \mathrm{~S}_{2} \mathrm{BrCl}_{2} \mathrm{~F}[\mathrm{M}+\mathrm{H}]^{+}: 501.8765$, found 501.8766 .

3.2.5. Synthesis of 6-Aminobenzo[ $[d]$ thiazole-2,7-dicarbonitrile (16) and Its Dimethylformimidamide Derivative (17)

tert-Butyl 2-cyano-4-nitrophenylcarbamate (11). To a solution of 2-amino-5-nitrobenzonitrile (1) $(10.0 \mathrm{~g}, 61.3 \mathrm{mmol})$ in dichloromethane $(100 \mathrm{~mL})$ were added triethylamine $(8.50 \mathrm{~mL}, 61.3 \mathrm{mmol})$, di-tert-butyl dicarbonate $(26.8 \mathrm{~g}, 123 \mathrm{mmol})$, and 4-(dimethylamino)pyridine (7.50 g, $61.3 \mathrm{mmol})$. The solution was stirred for $4 \mathrm{~h}$ at room temperature under an argon atmosphere. The solvent was removed in vacuo and the crude residue was purified by flash chromatography (DCM-petroleum ether, 8:2) to afford the expected compound 11 (14.6 g, 91\% yield) as a white solid; mp $=134-136{ }^{\circ} \mathrm{C}$. IR $\left(\mathrm{cm}^{-1}\right) v_{\max }$ 3412, 3072, 3012, 2982, 2935, 2229, 1735, 1617, 1582, 1543, 1508, 1473, 1455, 1420, 1372, 1350, 1320, 1303, 1257, 1234, 1176, 1143, 1052, 1028, 923, 915, 889, 853; . ${ }^{1} \mathrm{H}-\mathrm{NMR}$ (DMSO-d6) $\delta 10.04$ (s, $1 \mathrm{H}, \mathrm{NH}), 8.63(\mathrm{~d}, 1 \mathrm{H}, J=2.7 \mathrm{~Hz}), 8.44-8.40\left(\mathrm{dd}, 1 \mathrm{H}, J_{1}=2.7 \mathrm{~Hz}, J_{2}=9.3 \mathrm{~Hz}\right), 7.85(\mathrm{~d}, 1 \mathrm{H}, J=9.3 \mathrm{~Hz})$, 1.49 (s, 9H); ${ }^{13} \mathrm{C}-\mathrm{NMR}$ (DMSO- $d 6$ ) $\delta 153.1,146.6,142.6,129.3,128.8,123.4,115.2,105.3,81.2,27.3$; HRMS calcd for $\mathrm{C}_{12} \mathrm{H}_{12} \mathrm{~N}_{3} \mathrm{O}_{4}[\mathrm{M}+\mathrm{H}]^{+}:$262.0828, found 262.0831 . 
tert-Butyl 4-amino-2-cyanophenylcarbamate (12). A stirred mixture of 11 (10.0 g, 37.9 mmol), ammonium formate $(189.5 \mathrm{mmol})$ and palladium charcoal $(10 \%)$ in $300 \mathrm{~mL}$ of ethanol was heated at reflux under microwaves $(600 \mathrm{~W})$ for $30 \mathrm{~min}$. The catalyst was removed by filtration through Celite and washed with ethanol. The resulting filtrate was evaporated under reduced pressure. Then, the residue was dissolved in EtOAc, washed with water, dried over $\mathrm{MgSO}_{4}$ and concentrated under reduced pressure to give the reduced compound 12 ( $8.4 \mathrm{~g}, 95 \%$ yield) as a pale yellow solid, $\mathrm{mp}=126-128^{\circ} \mathrm{C}$. IR $\left(\mathrm{cm}^{-1}\right) v_{\max } 3476$, 3431, 3365, 3398, 2988, 2934, 2222, 1697, 1628, 1587, 1521, 1443, 1429, 1392, 1367, 1324, 1294, $1274,1250,1230,1161,1053,1028,947,902,872,849,824 ;{ }^{1} \mathrm{H}-\mathrm{NMR}$ (DMSO-d6) $\delta 8.82(\mathrm{~s}, 1 \mathrm{H}, \mathrm{NH})$, $7.02(\mathrm{~d}, 1 \mathrm{H}, J=8.1 \mathrm{~Hz}), 6.81(\mathrm{~s}, 1 \mathrm{H}), 6.78(\mathrm{~d}, 1 \mathrm{H}, J=2.7 \mathrm{~Hz}), 5.44\left(\mathrm{~s}, 2 \mathrm{H}, \mathrm{NH}_{2}\right), 1.43(\mathrm{~s}, 9 \mathrm{H})$; ${ }^{13} \mathrm{C}-\mathrm{NMR}\left(\mathrm{DMSO}-d_{6}\right) \delta 153.8,146.7,128.8,127.9,118.7,117.5,115.9,109.8,79.0,28.0$; HRMS calcd for $\mathrm{C}_{12} \mathrm{H}_{16} \mathrm{~N}_{3} \mathrm{O}_{2}[\mathrm{M}+\mathrm{H}]^{+}$: 234.1243, found 234.1240.

tert-Butyl 4-amino-3-bromo-2-cyanophenylcarbamate (13). A solution of bromine $(25.1 \mathrm{mmol})$ in dichloromethane $(1.3 \mathrm{~mL})$ was added dropwise, under an argon atmosphere, to a solution of amine $12(6.5 \mathrm{~g}, 27.9 \mathrm{mmol})$ in acetic acid $(325 \mathrm{~mL})$. After $2.5 \mathrm{~h}$ of stirring at room temperature, the solvent was removed in vacuo. The excess of acetic acid was co-evaporated with heptane to afford the expected compound 13 (10.1 g, 99\% yield) as a beige solid, $\mathrm{mp}=163-165^{\circ} \mathrm{C}$. IR $\left(\mathrm{cm}^{-1}\right) v_{\max } 3327,2826,2605$, 2566, 2236, 1955, 1716, 1610, 1561, 1496, 1481, 1398, 1369, 1280, 1238, 1193, 1153, 1059, 963, 906, 838; ${ }^{1} \mathrm{H}-\mathrm{NMR}\left(\mathrm{DMSO}-d_{6}\right) \delta 9.05(\mathrm{~s}, 1 \mathrm{H}, \mathrm{NH}), 7.11(\mathrm{~d}, 1 \mathrm{H}, J=8.7 \mathrm{~Hz}), 7.05$ (d, 1H, $\left.J=8.7 \mathrm{~Hz}\right), 6.01$ (s, $2 \mathrm{H}, \mathrm{NH}_{2}$ ), 1.43 (s, 9H); ${ }^{13} \mathrm{C}-\mathrm{NMR}$ (DMSO-d $) \delta 153.6,144.1,131.6,126.9,119.6,116.1,112.8,107.8$, 79.5, 28.1; HRMS calcd for $\mathrm{C}_{12} \mathrm{H}_{15} \mathrm{~N}_{3} \mathrm{O}_{2} \mathrm{Br}[\mathrm{M}+\mathrm{H}]^{+}: 312.0348$, found 312.0354.

tert-Butyl-3-bromo-4-(4-chloro-5H-1,2,3-dithiazol-5-ylideneamino)-2-cyanophenylcarbamate (14). A suspension of 13 (5.0 g, $16.0 \mathrm{mmol})$, 4,5-dichloro-1,2,3-dithiazolium chloride (7.34 g, $35.2 \mathrm{mmol})$ in dichloromethane $(100 \mathrm{~mL})$ was stirred at room temperature under argon atmosphere. After $3 \mathrm{~h}$ of stirring, pyridine $(5.7 \mathrm{~mL}, 70.5 \mathrm{mmol})$ was added and the mixture was stirred again for $1 \mathrm{~h}$ at room temperature. The resulting solution was concentrated under reduced pressure. The obtained crude residue was purified by flash chromatography (DCM-petroleum ether, 5:5) to afford the expected compound 14 (3.3 g, 46\% yield) as an orange solid, $\mathrm{mp}=140-150{ }^{\circ} \mathrm{C}(\mathrm{dec}) . \mathrm{IR}\left(\mathrm{cm}^{-1}\right) v_{\max } 3366,2977,2935,2227,1714,1597$, 1570, 1560, 1508, 1392, 1369, 1270, 1238, 1156, 1057, 971, 859, 846, 809; ${ }^{1} \mathrm{H}-\mathrm{NMR}$ (DMSO- $\left.d_{6}\right) \delta 9.64$ $(\mathrm{s}, 1 \mathrm{H}, \mathrm{NH}), 7.60(\mathrm{~d}, 1 \mathrm{H}, J=8.7 \mathrm{~Hz}), 7.55(\mathrm{~d}, 1 \mathrm{H}, J=8.7 \mathrm{~Hz}), 1.48(\mathrm{~s}, 9 \mathrm{H}) ;{ }^{13} \mathrm{C}-\mathrm{NMR}\left(\mathrm{DMSO}-d_{6}\right) \delta$ $163.5,152.9,147.4,146.0,140.0,126.1,123.6,117.7,115.3,112.2,80.4,27.9$; HRMS calcd for $\mathrm{C}_{14} \mathrm{H}_{13} \mathrm{~N}_{4} \mathrm{O}_{2} \mathrm{~S}_{2} \mathrm{BrCl}[\mathrm{M}+\mathrm{H}]^{+}:$446.9352, found 446.9340 .

6-Amino-2-bromo-3-(4-chloro-5H-1,2,3-dithiazol-5-ylideneamino)benzonitrile (15). A mixture of carbamate $14(3.3 \mathrm{~g}, 7.4 \mathrm{mmol})$ and acetic acid $(100 \mathrm{~mL})$ was heated at $118{ }^{\circ} \mathrm{C}$ under microwaves $(800 \mathrm{~W})$ for $2 \mathrm{~h}$. After cooling, the resulting solution was concentrated under reduced pressure to give the desired compound $\mathbf{1 5}$ (2.8 g, quantitative yield) as an orange solid, $\mathrm{mp}=188-198{ }^{\circ} \mathrm{C}$ (dec.). IR $\left(\mathrm{cm}^{-1}\right) v_{\max } / 3421,3340,3231,2220,1701,1647,1596,1575,1473,1405,1291,1251,1192,1137,973$, 869, 847, 804; ${ }^{1} \mathrm{H}-\mathrm{NMR}\left(\mathrm{DMSO}-d_{6}\right) \delta 7.36(\mathrm{~d}, 1 \mathrm{H}, J=9.0 \mathrm{~Hz}), 6.91(\mathrm{~d}, 1 \mathrm{H}, J=9.0 \mathrm{~Hz}), 6.55(\mathrm{~s}, 2 \mathrm{H}$, $\mathrm{NH}_{2}$ ); ${ }^{13} \mathrm{C}-\mathrm{NMR}$ (DMSO-d6) $\delta 159.6,151.7,146.7,137.8,124.4,119.0,116.4,115.7,97.2$; HRMS calcd for $\mathrm{C}_{9} \mathrm{H}_{5} \mathrm{~N}_{4} \mathrm{~S}_{2} \mathrm{BrCl}[\mathrm{M}+\mathrm{H}]^{+}$): 346.8828 , found 346.8846 . 
6-Aminobenzo[d] thiazole-2,7-dicarbonitrile (16). A suspension of imine 15 (2.5 g, $7.2 \mathrm{mmol})$, copper(I) iodide $(2.7 \mathrm{~g}, 14.4 \mathrm{mmol})$ in pyridine $(50 \mathrm{~mL})$ was heated at $130{ }^{\circ} \mathrm{C}$ under microwaves $(400 \mathrm{~W})$ for $20 \mathrm{~min}$. After cooling, the mixture was dissolved in EtOAc and washed with a sodium thiosulfate solution. The organic layer was dried over $\mathrm{MgSO}_{4}$, and the solvent was removed in vacuo. The crude residue was purified by flash chromatography (DCM-EtOAc, 9:1) to afford the expected compound 16 $(0.96 \mathrm{~g}, 67 \%$ yield $)$ as a pale brown solid; $\mathrm{mp}=248{ }^{\circ} \mathrm{C}$. IR $(\mathrm{KBr}) v_{\max } / \mathrm{cm}^{-1} 3433,3350,3250,2225$, $1653,1593,1487,1451,1415,1330,1290,1206,1161,1128,821 ;{ }^{1} \mathrm{H}-\mathrm{NMR}$ (DMSO-d $) \delta 8.11(\mathrm{~d}, 1 \mathrm{H}$, $J=9.3 \mathrm{~Hz}), 7.31\left(\mathrm{~s}, 2 \mathrm{H}, \mathrm{NH}_{2}\right), 7.10$ (d, $\left.1 \mathrm{H}, J=9.3 \mathrm{~Hz}\right) ;{ }^{13} \mathrm{C}-\mathrm{NMR}$ (DMSO-d6) $\delta 154.6,143.7,141.6$, 131.5, 130.9, 119.4, 116.9, 114.3, 83.6; HRMS calcd for $\mathrm{C}_{9} \mathrm{H}_{3} \mathrm{~N}_{4} \mathrm{~S}(\mathrm{M}-\mathrm{H})^{-}$: 199.0078, found 199.0076.

(E)-N'-(2,7-Dicyanobenzo[d] thiazol-6-yl)-N,N-dimethylformimidamide (17). A suspension of 16 (0.47 g, $2.34 \mathrm{mmol})$ in dimethylformamide dimethyl acetal $(6 \mathrm{~mL})$ was heated at $70{ }^{\circ} \mathrm{C}$ under microwaves $(600 \mathrm{~W})$ during $2 \mathrm{~min}$. After cooling, the brown precipitate formed was filtered, washed with $\mathrm{Et}_{2} \mathrm{O}$ and dried to afford the expected compound $17(0.51 \mathrm{~g}, 86 \%$ yield $)$ as a brown solid; $\mathrm{mp}=185-187^{\circ} \mathrm{C}$. IR $\left(\mathrm{cm}^{-1}\right) v_{\max } 2932,2901,2224,1622,1566,1500,1450,1410,1387,1368,1272,1229,1173,1099,1058$, 995, 964, 928, 874, 819; ${ }^{1} \mathrm{H}-\mathrm{NMR}$ (DMSO-d6) $\delta 8.33$ (d, 2H, $J=9.3 \mathrm{~Hz}$ ), 7.62 (d, $1 \mathrm{H}, J=9.3 \mathrm{~Hz}$ ), 3.15 $(\mathrm{s}, 3 \mathrm{H}), 3.07(\mathrm{~s}, 3 \mathrm{H}) ;{ }^{13} \mathrm{C}-\mathrm{NMR}\left(\mathrm{DMSO}-d_{6}\right) \delta 157.3,156.5,145.9,140.2,133.0,129.3,120.3,116.6$, 113.3, 96.4, 34.3; HRMS calcd for $\mathrm{C}_{12} \mathrm{H}_{10} \mathrm{~N}_{5} \mathrm{~S}[\mathrm{M}+\mathrm{H}]^{+}: 256.0657$, found 256.0644.

\subsubsection{Synthesis of Thiazolo[5,4-f]quinazoline-2-carbonitriles 7-10}

\section{A-General Procedure from $\mathbf{6 a}-\mathbf{d}$}

A suspension of imine $\mathbf{6 a}, \mathbf{6 c}$ and $\mathbf{6 d}(1 \mathrm{mmol})$, copper iodide $(2 \mathrm{mmol})$ in pyridine $(4 \mathrm{~mL})$ was heated at $120{ }^{\circ} \mathrm{C}(600 \mathrm{~W})$ for $20 \mathrm{~min}$. After cooling, the mixture was dissolved in ethyl acetate, washed with sodium thiosulfate solution. The organic layer was dried over $\mathrm{MgSO}_{4}$, and the solvent was removed in vacuo. The crude residue was purified by flash chromatography (DCM-EtOAc, 8:2) to afford the expected compounds 7,9 and 10.

\section{B-General Procedure from 17}

A mixture of $(E)-N^{\prime}$-(2,7-dicyanobenzo[d]thiazol-6-yl)- $N, N$-dimethylformimidamide $(\mathbf{1 7}, 0.05 \mathrm{~g}$, $0.19 \mathrm{mmol})$ and the appropriate amine $(0.29 \mathrm{mmol}, 1.5 \mathrm{eq})$ in acetic acid $(2 \mathrm{~mL})$ was heated under microwaves at $118{ }^{\circ} \mathrm{C}(600 \mathrm{~W})$. On completion (followed by TLC), the reaction was cooled to ambient temperature. The solvent was removed in vacuo and the crude residue was purified by flash chromatography to afford the expected compounds 7-10.

9-(4-Methoxyphenylamino)thiazolo[5,4-f] quinazoline-2-carbonitrile (7). Orange solid (yield: (A) 24\%; (B) $99 \%) ; \mathrm{mp}>260^{\circ} \mathrm{C}$. IR IR $\left(\mathrm{cm}^{-1}\right) v_{\max } 3346,2977,2361,2227,1644,1609,1581,1503,1460,1377$, 1354, 1303, 1239, 1164, 1129, 1051, 1032, 975, 829; ${ }^{1} \mathrm{H}-\mathrm{NMR}$ (DMSO-d6) $\delta 8.44(\mathrm{~s}, 1 \mathrm{H}), 7.95(\mathrm{~d}, 1 \mathrm{H}$, $J=9.0 \mathrm{~Hz}), 7.70(\mathrm{~d}, 1 \mathrm{H}, J=9.0 \mathrm{~Hz}), 7.45$ (d, 2H, $J=9.0 \mathrm{~Hz}), 6.99$ (d, 2H, $J=9.0 \mathrm{~Hz}), 3.76$ (s, 3H); HRMS calcd for $\mathrm{C}_{17} \mathrm{H}_{12} \mathrm{~N}_{5} \mathrm{OS}[\mathrm{M}+\mathrm{H}]^{+}: 334.0763$, found 334.0758 . 
9-(Benzo[d][1,3]dioxol-5-ylamino)thiazolo[5,4-f]quinazoline-2-carbonitrile (8). Orange solid (yield: (B) $95 \%) ; \mathrm{mp}>260{ }^{\circ} \mathrm{C}$. IR $\left(\mathrm{cm}^{-1}\right) v_{\max } 2894,2226,1734,1706,1645,1609,1581,1555,1499,1471$, 1377, 1354, 1304, 1264, $1236 \mathrm{KBr}, 1211,1188,1162,1125,1086,1037,972$, 938, 924, 859, 829, 809; ${ }^{1} \mathrm{H}-\mathrm{NMR}\left(\mathrm{DMSO}-d_{6}\right) \delta 8.51(\mathrm{~d}, 1 \mathrm{H}, J=9.0 \mathrm{~Hz}), 8.14(\mathrm{~m}, 1 \mathrm{H}), 7.76(\mathrm{~m}, 1 \mathrm{H}), 6.94(\mathrm{~d}, 2 \mathrm{H}, J=9.0 \mathrm{~Hz})$, $6.72(\mathrm{~m}, 1 \mathrm{H}), 6.02(\mathrm{~s}, 2 \mathrm{H})$; HRMS calcd for $\mathrm{C}_{17} \mathrm{H}_{9} \mathrm{~N}_{5} \mathrm{O}_{2} \mathrm{~S}[\mathrm{M}+\mathrm{H}]^{+}:$348.0555, found 348.0566.

9-(4-Bromo-2-fluorophenylamino)thiazolo[5,4-f]quinazoline-2-carbonitrile (9). Brown solid (yield: (A) $30 \%$; (B) 70\%); $\mathrm{mp}>260{ }^{\circ} \mathrm{C}$. IR $\left(\mathrm{cm}^{-1}\right) v_{\max } 3325,3053,2230,1649,1614,1582,1556,1499,1462$, 1380, 1351, 1250, 1154, 1132, 1052, 969, 904, 875, 817; ${ }^{19} \mathrm{~F}-\mathrm{NMR}$ (DMSO-d6) $\delta-119.9$; ${ }^{1} \mathrm{H}-\mathrm{NMR}$ $\left(\mathrm{DMSO}-d_{6}\right) \delta 8.55(\mathrm{~d}, 1 \mathrm{H}, J=9.0 \mathrm{~Hz}), 8.26(\mathrm{~d}, 1 \mathrm{H}, J=9.0 \mathrm{~Hz}), 7.78(\mathrm{~m}, 1 \mathrm{H}), 7.55-7.52(\mathrm{~m}, 1 \mathrm{H})$, 7.38-7.25 (m, 2H), HRMS calcd for $\mathrm{C}_{16} \mathrm{H}_{8} \mathrm{~N}_{5} \mathrm{SBrF}[\mathrm{M}+\mathrm{H}]^{+}:$399.9668, found 399.9662.

9-(3-Chloro-4-fluorophenylamino)thiazolo[5,4-f]quinazoline-2-carbonitrile (10). Yellow solid (yield: (A) $64 \%$; (B) $77 \%$ ); $\mathrm{mp}=252^{\circ} \mathrm{C}$. IR $\left(\mathrm{cm}^{-1}\right) v_{\max } 3456,3015,2970,2946,2229,1642,1441,1153,1129$, 1051, 968, 903, 817, 774, 695; ${ }^{19} \mathrm{~F}-\mathrm{NMR}$ (DMSO-d6) $\delta-123.8 ;{ }^{1} \mathrm{H}-\mathrm{NMR}$ (DMSO-d6) $\delta 8.43(\mathrm{~d}, 1 \mathrm{H}$, $J=9.0 \mathrm{~Hz}), 8.30(\mathrm{~s}, 1 \mathrm{H}), 7.62(\mathrm{~m}, 2 \mathrm{H}), 7.34(\mathrm{~m}, 2 \mathrm{H})$; HRMS calcd for $\mathrm{C}_{16} \mathrm{H}_{8} \mathrm{~N}_{5} \mathrm{SClF}[\mathrm{M}+\mathrm{H}]^{+}: 356.0156$, found 356.0167 .

\subsubsection{Synthesis of Carboximidamides $7 \mathbf{a}-\mathbf{g}, \mathbf{8 a}-\mathbf{g}, \mathbf{9 a}-\mathbf{g}$ and $\mathbf{1 0 a}-\mathbf{g}$}

General procedure: A stirred mixture of carbonitrile $16(1 \mathrm{mmol})$ and appropriate amine $(1.2 \mathrm{mmol})$ in dry THF $(7 \mathrm{~mL})$ under argon was stirred overnight at room temperature. The solvent was removed in vacuo and the crude residue purified by flash chromatography to afford the expected carboximidamides.

9-(4-Methoxyphenylamino)-N-(2-morpholinoethyl)thiazolo[5,4-f]quinazoline-2-carboximidamide (7a). Prepared from carbonitrile 7 and $\mathrm{N}$-aminoethylmorpholine. Flash chromatography eluent (DCM-MeOH, 5:5). Yellow solid (yield: $41 \%) ; \mathrm{mp}=130-132{ }^{\circ} \mathrm{C}$. IR $\left(\mathrm{cm}^{-1}\right) v_{\max } 3362,3175,2920,2852,1643,1567$, 1504, 1469, 1386, 1234, 1111, 1032, 964, 836; ${ }^{1} \mathrm{H}-\mathrm{NMR}$ (MeOD- $\left.d_{4}\right) \delta 8.37$ (d, 1H, $J=9.0 \mathrm{~Hz}$ ), 8.11 (s, $1 \mathrm{H}), 7.75(\mathrm{~d}, 1 \mathrm{H}, J=9.0 \mathrm{~Hz}), 7.26(\mathrm{~d}, 2 \mathrm{H}, J=9.0 \mathrm{~Hz}), 7.01(\mathrm{~d}, 2 \mathrm{H}, J=9.0 \mathrm{~Hz}), 3.82(\mathrm{~s}, 3 \mathrm{H}), 3.73(\mathrm{~m}$, $4 \mathrm{H}), 3.48(\mathrm{t}, 2 \mathrm{H}, J=7.0 \mathrm{~Hz}), 2.76(\mathrm{t}, 2 \mathrm{H}, J=7.0 \mathrm{~Hz}), 2.62(\mathrm{~m}, 4 \mathrm{H})$; HRMS calcd for $\mathrm{C}_{23} \mathrm{H}_{26} \mathrm{~N}_{7} \mathrm{O}_{2} \mathrm{~S}$ $[\mathrm{M}+\mathrm{H}]^{+}:$464.1869, found 464.1874 .

9-(4-Methoxyphenylamino)-N-(2-(piperidin-1-yl)ethyl)thiazolo[5,4-f] quinazoline-2-carboximidamide (7b). Prepared from carbonitrile 7 and $N$-aminoethylpiperidine. Flash chromatography eluent (DCM-MeOH, 3:7). Yellow solid (yield: 43\%); $\mathrm{mp}=132-134{ }^{\circ} \mathrm{C} . \mathrm{IR}\left(\mathrm{cm}^{-1}\right) v_{\max } 2933,2852,1640$, $1613,1572,1507,1376,1349,1302,1283,1237,1155,1124,1035,962,833 ;{ }^{1} \mathrm{H}-\mathrm{NMR}$ (MeOD- $\left.d_{4}\right) \delta$ $8.34(\mathrm{~d}, 1 \mathrm{H}, J=9.0 \mathrm{~Hz}), 8.08(\mathrm{~s}, 1 \mathrm{H}), 7.73(\mathrm{~d}, 1 \mathrm{H}, J=9.0 \mathrm{~Hz}), 7.23$ (d, 2H, $J=9.0 \mathrm{~Hz}), 6.99$ (d, 2H, $J=9.0 \mathrm{~Hz}), 3.82(\mathrm{~s}, 3 \mathrm{H}), 3.49$ (t, 2H, $J=7.0 \mathrm{~Hz}), 2.73(\mathrm{t}, 2 \mathrm{H}, J=7.0 \mathrm{~Hz}), 2.56(\mathrm{~m}, 4 \mathrm{H}), 1.66(\mathrm{~m}, 4 \mathrm{H}), 1.52$ (m, 2H); HRMS calcd for $\mathrm{C}_{24} \mathrm{H}_{28} \mathrm{~N}_{7} \mathrm{OS}[\mathrm{M}+\mathrm{H}]^{+}$: 462.2076, found 462.2098.

9-(4-Methoxyphenylamino)-N-(2-(pyrrolidin-1-yl)ethyl)thiazolo[5,4-f]quinazoline-2-carboximidamide (7c). Prepared from carbonitrile 7 and $N$-aminoethylpyrrolidine. Flash chromatography eluent (DCM-MeOH, 5:5). Orange solid (yield: 47\%); $\mathrm{mp}=134-136{ }^{\circ} \mathrm{C} . \mathrm{IR}\left(\mathrm{cm}^{-1}\right) v_{\max } 2957,2798,1643$, $1615,1573,1504,1379,1341,1284,1237,1147,1086,1033,962,880,833 ;{ }^{1}$ H-NMR (MeOD- $\left.d_{4}\right) \delta$ 
$8.34(\mathrm{~d}, 1 \mathrm{H}, J=9.0 \mathrm{~Hz}), 8.08(\mathrm{~s}, 1 \mathrm{H}), 7.73(\mathrm{~d}, 1 \mathrm{H}, J=9.0 \mathrm{~Hz}), 7.23(\mathrm{~d}, 2 \mathrm{H}, J=9.0 \mathrm{~Hz}), 6.99(\mathrm{~d}, 2 \mathrm{H}$, $J=9.0 \mathrm{~Hz}), 3.82(\mathrm{~s}, 3 \mathrm{H}), 3.49$ (t, 2H, $J=7.0 \mathrm{~Hz}), 2.88(\mathrm{t}, 2 \mathrm{H}, J=7.0 \mathrm{~Hz}), 2.67(\mathrm{~m}, 4 \mathrm{H}), 1.85(\mathrm{~m}, 4 \mathrm{H})$; HRMS calcd for $\mathrm{C}_{23} \mathrm{H}_{26} \mathrm{~N}_{7} \mathrm{OS}[\mathrm{M}+\mathrm{H}]^{+}$: 448.1920, found 448.1926.

N-(2-(Dimethylamino)ethyl)-9-(4-methoxyphenylamino)thiazolo[5,4-f] quinazoline-2-carboximidamide (7d). Prepared from carbonitrile 7 and 2-dimethylaminoethylamine. Flash chromatography eluent (DCM-MeOH, 5:5). Yellow solid (yield: 53\%); $\mathrm{mp}=154-156^{\circ} \mathrm{C}$. IR $\left(\mathrm{cm}^{-1}\right) v_{\max } 2945,2827,2773$, $1643,1614,1572,1505,1464,1379,1341,1237,1177,1033,962,832 ;{ }^{1} \mathrm{H}-\mathrm{NMR}$ (MeOD-d4) $\delta 8.30(\mathrm{~d}, 1 \mathrm{H}$, $J=9.0 \mathrm{~Hz}), 8.06(\mathrm{~s}, 1 \mathrm{H}), 7.69(\mathrm{~d}, 1 \mathrm{H}, J=9.0 \mathrm{~Hz}), 7.22(\mathrm{~d}, 2 \mathrm{H}, J=9.0 \mathrm{~Hz}), 6.97(\mathrm{~d}, 2 \mathrm{H}$, $J=9.0 \mathrm{~Hz}), 3.81(\mathrm{~s}, 3 \mathrm{H}), 3.43(\mathrm{t}, 2 \mathrm{H}, J=7.0 \mathrm{~Hz}), 2.70(\mathrm{t}, 2 \mathrm{H}, J=7.0 \mathrm{~Hz}), 2.34(\mathrm{~s}, 6 \mathrm{H})$; HRMS calcd for $\mathrm{C}_{21} \mathrm{H}_{24} \mathrm{~N}_{7} \mathrm{OS}[\mathrm{M}+\mathrm{H}]^{+}$: 422.1763, found 422.1766 .

\section{N-(2-(Diethylamino)ethyl)-9-(4-methoxyphenylamino)thiazolo[5,4-f] quinazoline-2-carboximidamide}

(7e). Prepared from carbonitrile 7 and diethylethylenediamine. Flash chromatography eluent (DCM-MeOH, 5:5). Yellow solid (yield: 50\%); $\mathrm{mp}=103-105{ }^{\circ} \mathrm{C} . \mathrm{IR}\left(\mathrm{cm}^{-1}\right) v_{\max } 2967,2832,1641$, 1614, 1572, 1507, 1378, 1341, 1285, 1237, 1178, 1086, 1034, 962, 834; ${ }^{1} \mathrm{H}-\mathrm{NMR}$ (MeOD-d4) $\delta 8.35$ (d, 1H, $J=9.0 \mathrm{~Hz}), 8.08(\mathrm{~s}, 1 \mathrm{H}), 7.74(\mathrm{~d}, 1 \mathrm{H}, J=9.0 \mathrm{~Hz}), 7.23(\mathrm{~d}, 2 \mathrm{H}, J=9.0 \mathrm{~Hz}), 7.01(\mathrm{~d}, 2 \mathrm{H}$, $J=9.0 \mathrm{~Hz}), 3.82(\mathrm{~s}, 3 \mathrm{H}), 3.43(\mathrm{t}, 2 \mathrm{H}, J=7.0 \mathrm{~Hz}), 2.86(\mathrm{t}, 2 \mathrm{H}, J=7.0 \mathrm{~Hz}), 2.71$ (q, 4H, $J=7.0 \mathrm{~Hz}), 1.11$ $\left(\mathrm{t}, 6 \mathrm{H}, J=7.0 \mathrm{~Hz}\right.$ ); HRMS calcd for $\mathrm{C}_{23} \mathrm{H}_{28} \mathrm{~N}_{7} \mathrm{OS}[\mathrm{M}+\mathrm{H}]^{+}: 450.2076$, found 450.2058.

N-Benzyl-9-(4-methoxyphenylamino)thiazolo[5,4-f]quinazoline-2-carboximidamide (7f). Prepared from carbonitrile 7 and benzylamine. Flash chromatography eluent (DCM-EtOAc, 2:8). Yellow solid (yield: $28 \%) ; \mathrm{mp}=128-130{ }^{\circ} \mathrm{C}$. IR $\left(\mathrm{cm}^{-1}\right) v_{\max } 3362,3028,2832,1640,1598,1572,1509,1377,1356,1299$, 1238, 1177, 1084, 1030, 962, 833; ${ }^{1} \mathrm{H}-\mathrm{NMR}\left(\mathrm{MeOD}-d_{4}\right) \delta 8.34(\mathrm{~d}, 1 \mathrm{H}, J=9.0 \mathrm{~Hz}), 8.08(\mathrm{~s}, 1 \mathrm{H}), 7.73(\mathrm{~d}$, $1 \mathrm{H}, J=9.0 \mathrm{~Hz}), 7.35(\mathrm{~m}, 4 \mathrm{H}), 7.26(\mathrm{~m}, 3 \mathrm{H}), 6.99(\mathrm{~d}, 2 \mathrm{H}, J=9.0 \mathrm{~Hz}), 4.55(\mathrm{~s}, 2 \mathrm{H}), 3.83(\mathrm{~s}, 3 \mathrm{H})$; HRMS calcd for $\mathrm{C}_{24} \mathrm{H}_{21} \mathrm{~N}_{6} \mathrm{OS}[\mathrm{M}+\mathrm{H}]^{+}$: 441.1498, found 441.1507 .

9-(4-Methoxyphenylamino)-N,N-dimethylthiazolo[5,4-f] quinazoline-2-carboximidamide (7g). Prepared from carbonitrile 7 and dimethylamine. Flash chromatography eluent (DCM-MeOH, 5:5). Pale yellow solid (yield: $67 \%) ; \mathrm{mp}=150-152{ }^{\circ} \mathrm{C}$. IR $(\mathrm{KBr}) v_{\max } / \mathrm{cm}^{-1} 3139,2924,1681,1644,1571,1509,1383$, 1347, 1286, 1237, 1176, 1031, 966, 834; ${ }^{1} \mathrm{H}-\mathrm{NMR}\left(\mathrm{MeOD}-d_{4}\right) \delta 8.15$ (d, $\left.1 \mathrm{H}, J=9.0 \mathrm{~Hz}\right), 7.84(\mathrm{~s}, 1 \mathrm{H})$, $7.53(\mathrm{~d}, 1 \mathrm{H}, J=9.0 \mathrm{~Hz}), 7.08$ (d, 2H, $J=9.0 \mathrm{~Hz}), 6.89$ (d, 2H, $J=9.0 \mathrm{~Hz}), 3.77$ (s, 3H), $3.13(\mathrm{~s}, 6 \mathrm{H})$; HRMS calcd for $\mathrm{C}_{19} \mathrm{H}_{19} \mathrm{~N}_{6} \mathrm{OS}[\mathrm{M}+\mathrm{H}]^{+}: 379.1341$, found 379.1333 .

9-(Benzo[d][1,3]dioxol-5-ylamino)-N-(2-morpholinoethyl)thiazolo[5,4-f]quinazoline-2-carboximidamide

(8a). Prepared from carbonitrile 8 and $N$-aminoethylmorpholine. Flash chromatography eluent (DCM-MeOH, 5:5). Yellow solid (yield: 41\%); $\mathrm{mp}=168-170{ }^{\circ} \mathrm{C}$. IR $\left(\mathrm{cm}^{-1}\right) v_{\max } 3324,2965,2901$, 2861, 2812, 1641, 1616, 1587, 1503, 1468, 1382, 1353, 1304, 1271, 1232, 1180, 1148, 1114, 1067, 1036, 969, 935, 839; ${ }^{1} \mathrm{H}-\mathrm{NMR}\left(\mathrm{MeOD}-d_{4}\right) \delta 8.33(\mathrm{~d}, 1 \mathrm{H}, J=9.0 \mathrm{~Hz}), 7.96(\mathrm{~s}, 1 \mathrm{H}), 7.71(\mathrm{~d}, 1 \mathrm{H}, J=9.0 \mathrm{~Hz})$, $6.87(\mathrm{~d}, 1 \mathrm{H}, J=9.0 \mathrm{~Hz}), 6.74(\mathrm{~s}, 1 \mathrm{H}), 6.64(\mathrm{~d}, 1 \mathrm{H}, J=9.0 \mathrm{~Hz}), 5.96(\mathrm{~s}, 2 \mathrm{H}), 3.74(\mathrm{~m}, 4 \mathrm{H}), 3.55(\mathrm{t}, 2 \mathrm{H}$, $J=7.0 \mathrm{~Hz}), 2.75(\mathrm{t}, 2 \mathrm{H}, J=7.0 \mathrm{~Hz}), 2.61(\mathrm{~m}, 4 \mathrm{H})$; HRMS calcd for $\mathrm{C}_{23} \mathrm{H}_{24} \mathrm{~N}_{7} \mathrm{O}_{3} \mathrm{~S}[\mathrm{M}+\mathrm{H}]^{+}: 478.1661$, found 478.1649 . 
9-(Benzo[d][1,3] dioxol-5-ylamino)-N-(2-(piperidin-1-yl)ethyl)thiazolo[5,4-f]quinazoline-2-carboximidamide (8b). Prepared from carbonitrile $\mathbf{8}$ and $N$-aminoethylpiperidine. Flash chromatography eluent (DCM-MeOH, 3:7). Yellow solid (yield: 34\%); $m p=170-172{ }^{\circ} \mathrm{C} . \mathrm{IR}\left(\mathrm{cm}^{-1}\right) v_{\max } 3350,2936,2773$, 2482, 2061, 1641, 1613, 1585, 1503, 1462, 1374, 1337, 1304, 1229, 1176, 1141, 1121, 1037, 983, 962 , 931, 855, 832; ${ }^{1} \mathrm{H}-\mathrm{NMR}\left(\mathrm{MeOD}-d_{4}\right) \delta 8.33(\mathrm{~d}, 1 \mathrm{H}, J=9.0 \mathrm{~Hz}), 7.89$ (s, 1H), 7.69 (d, $1 \mathrm{H}, J=9.0 \mathrm{~Hz}$ ), $6.86(\mathrm{~d}, 1 \mathrm{H}, J=9.0 \mathrm{~Hz}), 6.75(\mathrm{~s}, 1 \mathrm{H}), 6.63(\mathrm{~d}, 1 \mathrm{H}, J=9.0 \mathrm{~Hz}), 5.99(\mathrm{~s}, 2 \mathrm{H}), 3.46(\mathrm{t}, 2 \mathrm{H}, J=7.0 \mathrm{~Hz})$, $2.71(\mathrm{t}, 2 \mathrm{H}, J=7.0 \mathrm{~Hz}), 2.57(\mathrm{~m}, 4 \mathrm{H}), 1.64(\mathrm{~m}, 4 \mathrm{H}), 1.50(\mathrm{~m}, 2 \mathrm{H})$; HRMS calcd for $\mathrm{C}_{24} \mathrm{H}_{26} \mathrm{~N}_{7} \mathrm{O}_{2} \mathrm{~S}$ $[\mathrm{M}+\mathrm{H}]^{+}:$476.1869, found 476.1883 .

9-(Benzo[d] [1,3] dioxol-5-ylamino)-N-(2-(pyrrolidin-1-yl)ethyl)thiazolo[5,4-f]quinazoline-2-carboximidamide (8c). Prepared from carbonitrile 8 and $N$-aminoethylpyrrolidine. Flash chromatography eluent (DCM-MeOH, 5:5). Yellow solid (yield: 48\%); $\mathrm{mp}=172-174{ }^{\circ} \mathrm{C} . \mathrm{IR}\left(\mathrm{cm}^{-1}\right) v_{\max } 2906,2803,1643$, 1614, 1573, 1500, 1467, 1377, 1347, 1305, 1265, 1228, 1175, 1121, 1036, 966, 933, 833; ${ }^{1} \mathrm{H}-\mathrm{NMR}$ $\left(\mathrm{MeOD}-d_{4}\right) \delta 8.27(\mathrm{~d}, 1 \mathrm{H}, J=9.0 \mathrm{~Hz}), 7.90(\mathrm{~s}, 1 \mathrm{H}), 7.65(\mathrm{~d}, 1 \mathrm{H}, J=9.0 \mathrm{~Hz}), 6.86(\mathrm{~d}, 1 \mathrm{H}, J=9.0 \mathrm{~Hz})$, $6.75(\mathrm{~s}, 1 \mathrm{H}), 6.63(\mathrm{~d}, 1 \mathrm{H}, J=9.0 \mathrm{~Hz}), 5.97(\mathrm{~s}, 2 \mathrm{H}), 3.46(\mathrm{t}, 2 \mathrm{H}, J=7.0 \mathrm{~Hz}), 2.85(\mathrm{t}, 2 \mathrm{H}, J=7.0 \mathrm{~Hz}), 2.67$ $(\mathrm{m}, 4 \mathrm{H}), 1.83(\mathrm{~m}, 4 \mathrm{H})$; HRMS calcd for $\mathrm{C}_{23} \mathrm{H}_{24} \mathrm{~N}_{7} \mathrm{O}_{2} \mathrm{~S}[\mathrm{M}+\mathrm{H}]^{+}: 462.1712$, found 462.1736 .

9-(Benzo[d][1,3]dioxol-5-ylamino)-N-(2-(dimethylamino)ethyl)thiazolo[5,4-f]quinazoline-2-carboximidamide (8d). Prepared from carbonitrile 8 and 2-dimethylaminoethylamine. Flash chromatography eluent (DCM-MeOH, 5:5). Yellow solid (yield: 10\%); $\mathrm{mp}>260{ }^{\circ} \mathrm{C}$. IR $\left(\mathrm{cm}^{-1}\right) v_{\max } 3391,2923,2852$, 1643, 1615, 1538, 1498, 1467, 1383, 1346, 1302, 1263, 1229, 1178, 1118, 1035, 965, 933, 856, 835; ${ }^{1} \mathrm{H}-\mathrm{NMR}\left(\mathrm{MeOD}-d_{4}\right) \delta 8.17(\mathrm{~d}, 1 \mathrm{H}, J=9.0 \mathrm{~Hz}), 7.90(\mathrm{~s}, 1 \mathrm{H}), 7.56(\mathrm{~d}, 1 \mathrm{H}, J=9.0 \mathrm{~Hz}), 6.86(\mathrm{~d}, 1 \mathrm{H}$, $J=9.0 \mathrm{~Hz}), 6.75(\mathrm{~s}, 1 \mathrm{H}), 6.63(\mathrm{~d}, 1 \mathrm{H}, J=9.0 \mathrm{~Hz}), 5.91(\mathrm{~s}, 2 \mathrm{H}), 3.43(\mathrm{t}, 2 \mathrm{H}, J=7.0 \mathrm{~Hz}), 2.69(\mathrm{t}, 2 \mathrm{H}$, $J=7.0 \mathrm{~Hz}$ ), $2.33(\mathrm{~s}, 6 \mathrm{H})$; HRMS calcd for $\mathrm{C}_{21} \mathrm{H}_{22} \mathrm{~N}_{7} \mathrm{O}_{2} \mathrm{~S}[\mathrm{M}+\mathrm{H}]^{+}: 436.1556$, found 436.1549 .

\section{9-(Benzo[d][1,3]dioxol-5-ylamino)-N-(2-(diethylamino)ethyl)thiazolo[5,4-f]quinazoline-2-carboxi-}

midamide (8e). Prepared from carbonitrile 8 and diethylethylenediamine. Flash chromatography eluent (DCM-MeOH, 5:5). Yellow solid (yield: 44\%); $\mathrm{mp}=144-146{ }^{\circ} \mathrm{C} . \mathrm{IR}\left(\mathrm{cm}^{-1}\right) v_{\max } 3333,2970,2920$, 2832, 1641, 1614, 1585, 1502, 1463, 1421, 1378, 1348, 1303, 1231, 1179, 1145, 1122, 1088, 1037, 965, 933, 858, 831; ${ }^{1} \mathrm{H}-\mathrm{NMR}\left(\mathrm{MeOD}-d_{4}\right) \delta 8.23(\mathrm{~d}, 1 \mathrm{H}, J=9.0 \mathrm{~Hz}), 7.89(\mathrm{~s}, 1 \mathrm{H}), 7.62(\mathrm{~d}, 1 \mathrm{H}, J=9.0 \mathrm{~Hz})$, $6.86(\mathrm{~d}, 1 \mathrm{H}, J=9.0 \mathrm{~Hz}), 6.75(\mathrm{~s}, 1 \mathrm{H}), 6.63(\mathrm{~d}, 1 \mathrm{H}, J=9.0 \mathrm{~Hz}), 5.94(\mathrm{~s}, 2 \mathrm{H}), 3.42(\mathrm{t}, 2 \mathrm{H}, J=7.0 \mathrm{~Hz})$, $2.83(\mathrm{t}, 2 \mathrm{H}, J=7.0 \mathrm{~Hz}), 2.68(\mathrm{q}, 4 \mathrm{H}, J=7.0 \mathrm{~Hz}), 1.10(\mathrm{t}, 6 \mathrm{H}, J=7.0 \mathrm{~Hz}) ; \mathrm{HRMS}$ calcd for $\mathrm{C}_{23} \mathrm{H}_{26} \mathrm{~N}_{7} \mathrm{O}_{2} \mathrm{~S}$ $[\mathrm{M}+\mathrm{H}]^{+}:$464.1869, found 464.1896 .

9-(Benzo[d] [1,3]dioxol-5-ylamino)-N-benzylthiazolo[5,4-f] quinazoline-2-carboximidamide

(8f).

Prepared from carbonitrile $\mathbf{8}$ and benzylamine. Flash chromatography eluent (DCM-EtOAc, 2:8). Yellow solid (yield: $21 \%$ ); $\mathrm{mp}>260{ }^{\circ} \mathrm{C}$. IR $\left(\mathrm{cm}^{-1}\right) v_{\max } 2886,2447,1641,1597,1497,1466,1413$, 1384, 1353, 1307, 1266, 1229, 1178, 1122, 1105, 1036, 967, 934, 861, 833; ${ }^{1} \mathrm{H}-\mathrm{NMR}$ (MeOD- $\left.d_{4}\right) \delta 8.27$ $(\mathrm{d}, 1 \mathrm{H}, J=9.0 \mathrm{~Hz}), 7.90(\mathrm{~s}, 1 \mathrm{H}), 7.65(\mathrm{~d}, 1 \mathrm{H}, J=9.0 \mathrm{~Hz}), 6.86(\mathrm{~m}, 4 \mathrm{H}), 6.75(\mathrm{~m}, 3 \mathrm{H}), 6.63(\mathrm{~d}, 1 \mathrm{H}$, $J=9.0 \mathrm{~Hz}), 5.97(\mathrm{~s}, 2 \mathrm{H}), 4.58(\mathrm{~s}, 2 \mathrm{H})$; HRMS calcd for $\mathrm{C}_{24} \mathrm{H}_{19} \mathrm{~N}_{6} \mathrm{O}_{2} \mathrm{~S}[\mathrm{M}+\mathrm{H}]^{+}:$455.1290, found 455.1287 .

9-(4-Bromo-2-fluorophenylamino)-N-(2-morpholinoethyl)thiazolo[5,4-f] quinazoline-2-carboximid-amide (9a). Prepared from carbonitrile 9 and $N$-aminoethylmorpholine. Flash chromatography eluent 
(DCM-MeOH, 5:5). Yellow solid (yield: 85\%); $\mathrm{mp}=190-192{ }^{\circ} \mathrm{C} . \mathrm{IR}\left(\mathrm{cm}^{-1}\right) v_{\max } 3374,2975,2361$, 1645, 1585, 1381, 1265, 1227, 1090, 1053, 973, 916, 882, 825; ${ }^{19} \mathrm{~F}-\mathrm{NMR}$ (DMSO-d6) $\delta-120.0$; ${ }^{1} \mathrm{H}-\mathrm{NMR}\left(\mathrm{DMSO}-d_{6}\right) \delta 8.52(\mathrm{~d}, 1 \mathrm{H}, J=9.0 \mathrm{~Hz}), 8.26(\mathrm{~m}, 1 \mathrm{H}), 7.78(\mathrm{~m}, 1 \mathrm{H}), 7.57(\mathrm{~m}, 1 \mathrm{H}), 7.36(\mathrm{~m}$, $1 \mathrm{H}), 7.16(\mathrm{~m}, 1 \mathrm{H}), 3.66(\mathrm{t}, 4 \mathrm{H}, J=4.5 \mathrm{~Hz}), 3.48-3.42(\mathrm{~m}, 2 \mathrm{H}), 2.69(\mathrm{t}, 2 \mathrm{H}, J=6.0 \mathrm{~Hz}), 2.61(\mathrm{~m}, 4 \mathrm{H})$; HRMS calcd for $\mathrm{C}_{22} \mathrm{H}_{22} \mathrm{~N} 7 \mathrm{OSBrF}[\mathrm{M}+\mathrm{H}]^{+}: 530.0774$, found 530.0782 .

9-(4-Bromo-2-fluorophenylamino)-N-(2-(piperidin-1-yl)ethyl)thiazolo[5,4-f]quinazoline-2-carboximidamide (9b). Prepared from carbonitrile 9 and $N$-aminoethylpiperidine. Flash chromatography eluent (DCM-MeOH, 5:5). Yellow solid (yield: 72\%); $\mathrm{mp}=142-144{ }^{\circ} \mathrm{C}$. IR $\left(\mathrm{cm}^{-1}\right) v_{\max } 3340,2975,2930$, 2361, 1615, 1561, 1476, 1380, 1348, 1262, 1197, 1153, 1114, 1052, 881, 821; ${ }^{19} \mathrm{~F}-\mathrm{NMR}\left(\mathrm{CDCl}_{3}\right) \delta-123.8$; ${ }^{1} \mathrm{H}-\mathrm{NMR}\left(\mathrm{CDCl}_{3}\right) \delta 8.25(\mathrm{~d}, 1 \mathrm{H}, J=9.0 \mathrm{~Hz}), 8.09(\mathrm{~s}, 1 \mathrm{H}), 7.55(\mathrm{~d}, 1 \mathrm{H}, J=9.0 \mathrm{~Hz}), 7.50-7.45(\mathrm{~m}, 1 \mathrm{H})$, $7.29(\mathrm{t}, 1 \mathrm{H}, J=9.0 \mathrm{~Hz}), 7.12-7.06(\mathrm{~m}, 1 \mathrm{H}), 3.54(\mathrm{~m}, 2 \mathrm{H}), 2.67(\mathrm{t}, 2 \mathrm{H}, J=5.7 \mathrm{~Hz}), 2.54(\mathrm{~m}, 4 \mathrm{H})$, 1.66-1.60 (m, 4H), 1.49 (m, 2H); HRMS calcd for $\mathrm{C}_{23} \mathrm{H}_{24} \mathrm{~N}_{7} \mathrm{SBrF}[\mathrm{M}+\mathrm{H}]^{+}$: 528.0981, found 528.0986.

9-(4-Bromo-2-fluorophenylamino)-N-(2-(pyrrolidin-1-yl)ethyl)thiazolo[5,4-f] quinazoline-2-carboximidamide (9c). Prepared from carbonitrile 9 and $N$-aminoethylpyrrolidine. Flash chromatography eluent (DCM-MeOH, 5:5). Orange solid (yield: 68\%); $\mathrm{mp}=138-140{ }^{\circ} \mathrm{C} . \mathrm{IR}\left(\mathrm{cm}^{-1}\right) v_{\max } 2968,2361,1563$, 1476, 1380, 1262, 1223, 1067, 965, 880, 822; ${ }^{19} \mathrm{~F}-\mathrm{NMR}\left(\mathrm{MeOD}-d_{4}\right) \delta-123.6 ;{ }^{1} \mathrm{H}-\mathrm{NMR}\left(\mathrm{MeOD}-d_{4}\right) \delta$ $8.29(\mathrm{~d}, 1 \mathrm{H}, J=9.0 \mathrm{~Hz}), 7.89(\mathrm{~s}, 1 \mathrm{H}), 7.63(\mathrm{~d}, 1 \mathrm{H}, J=9.0 \mathrm{~Hz}), 7.35-7.29$ (m, 2H), 7.09 (t, 1H, $J=9.0 \mathrm{~Hz})$, $3.46(\mathrm{t}, 2 \mathrm{H}, J=6.6 \mathrm{~Hz}), 2.87(\mathrm{t}, 2 \mathrm{H}, J=6.6 \mathrm{~Hz}), 2.69(\mathrm{~m}, 4 \mathrm{H}), 1.89(\mathrm{~m}, 4 \mathrm{H})$; HRMS calcd for $\mathrm{C}_{22} \mathrm{H}_{22} \mathrm{~N}_{7} \mathrm{SBrF}[\mathrm{M}+\mathrm{H}]^{+}: 514.0825$, found 514.0825 .

9-(4-Bromo-2-fluorophenylamino)-N-(2-(dimethylamino)ethyl)thiazolo[5,4-f]quinazoline-2-carboximidamide (9d). Prepared from carbonitrile 9 and 2-dimethylaminoethylamine. Flash chromatography eluent (DCM-MeOH, 5:5). Orange solid (yield: $64 \%$ ); $\mathrm{mp}=128-130{ }^{\circ} \mathrm{C}$. IR $\left(\mathrm{cm}^{-1}\right) v_{\max } 3274,3058$, 2940, 2861, 2822, 2773, 1618, 1560, 1478, 1380, 1341, 1262, 1197, 1155, 1112, 1038, 965, 881, 823; ${ }^{19} \mathrm{~F}-\mathrm{NMR}\left(\mathrm{MeOD}-d_{4}\right) \delta-122.3 ;{ }^{1} \mathrm{H}-\mathrm{NMR}\left(\mathrm{MeOD}-d_{4}\right) \delta 8.33(\mathrm{~d}, 1 \mathrm{H}, J=9.0 \mathrm{~Hz}), 7.92(\mathrm{~s}, 1 \mathrm{H}), 7.68$ $(\mathrm{d}, 1 \mathrm{H}, J=9.0 \mathrm{~Hz}), 7.41-7.36(\mathrm{~m}, 2 \mathrm{H}), 7.15(\mathrm{t}, 1 \mathrm{H}, J=9.0 \mathrm{~Hz}), 3.46(\mathrm{t}, 2 \mathrm{H}, J=6.6 \mathrm{~Hz}), 2.76(\mathrm{t}, 2 \mathrm{H}$, $J=6.6 \mathrm{~Hz}$ ), $2.37(\mathrm{~s}, 6 \mathrm{H})$; HRMS calcd for $\mathrm{C}_{20} \mathrm{H}_{20} \mathrm{~N}_{7} \mathrm{SBrF}[\mathrm{M}+\mathrm{H}]^{+}: 488.0668$, found 488.0688 .

9-(4-Bromo-2-fluorophenylamino)-N-(2-(diethylamino)ethyl)thiazolo[5,4-f] quinazoline-2-carboximidamide (9e). Prepared from carbonitrile 9 and diethylethylenediamine. Flash chromatography eluent $(\mathrm{DCM}-\mathrm{MeOH}, 5: 5)$. Orange solid (yield: $86 \%) ; \mathrm{mp}=88-100{ }^{\circ} \mathrm{C} . \mathrm{IR}\left(\mathrm{cm}^{-1}\right) v_{\max } 2965,2360,1793$, 1619, 1520, 1477, 1378, 1265, 1198, 1067, 966, 880, 822; ${ }^{19} \mathrm{~F}-\mathrm{NMR}$ (MeOD-d $) \delta-122.1$; ${ }^{1} \mathrm{H}-\mathrm{NMR}$ $\left(\mathrm{MeOD}-d_{4}\right) \delta 8.30(\mathrm{~d}, 1 \mathrm{H}, J=9.0 \mathrm{~Hz}), 7.93(\mathrm{~s}, 1 \mathrm{H}), 7.66(\mathrm{~d}, 1 \mathrm{H}, J=9.0 \mathrm{~Hz}), 7.38-7.33(\mathrm{~m}, 2 \mathrm{H}), 7.13$ (t, 1H, $J=9.0 \mathrm{~Hz}), 3.58(\mathrm{t}, 2 \mathrm{H}, J=6.6 \mathrm{~Hz}), 2.82(\mathrm{t}, 2 \mathrm{H}, J=6.6 \mathrm{~Hz}), 2.68(\mathrm{~m}, 4 \mathrm{H}), 1.09(\mathrm{~m}, 6 \mathrm{H})$; HRMS calcd for $\mathrm{C}_{22} \mathrm{H}_{24} \mathrm{~N}_{7} \mathrm{SBrF}[\mathrm{M}+\mathrm{H}]^{+}:$516.0981, found 516.0988.

N-Benzyl-9-(4-bromo-2-fluorophenylamino)thiazolo[5,4-f] quinazoline-2-carboximidamide(9f). Prepared from carbonitrile 9 and benzylamine. Flash chromatography eluent (DCM-EtOAc, 2:8). Yellow solid (yield: $68 \%) ; \mathrm{mp}=130-132{ }^{\circ} \mathrm{C} . \mathrm{IR}\left(\mathrm{cm}^{-1}\right) v_{\max } 2964,2903,2360,1815,1614,1477,1379,1262,1153$, 1113, 1069, 966, 880, 821; ${ }^{19} \mathrm{~F}-\mathrm{NMR}\left(\mathrm{MeOD}-d_{4}\right) \delta-122.2 ;{ }^{1} \mathrm{H}-\mathrm{NMR}\left(\mathrm{MeOD}-d_{4}\right) \delta 8.35(\mathrm{~d}, 1 \mathrm{H}$, 
$J=9.0 \mathrm{~Hz}), 7.92(\mathrm{~s}, 1 \mathrm{H}), 7.69$ (d, 1H, $J=9.0 \mathrm{~Hz}), 7.43$ (m, 3H), 7.39-7.30 (m, 3H), 7.25 (m, 1H), 7.15 (t, $1 \mathrm{H}, J=9.0 \mathrm{~Hz}), 4.53(\mathrm{~s}, 2 \mathrm{H})$; HRMS calcd for $\mathrm{C}_{23} \mathrm{H}_{17} \mathrm{~N}_{6} \mathrm{SBrF}[\mathrm{M}+\mathrm{H}]^{+}: 507.0403$, found 507.0412.

9-(4-Bromo-2-fluorophenylamino)-N-(2-(dimethylamino)ethyl)thiazolo[5,4-f]quinazoline-2-carboximidamide (9g). Prepared from carbonitrile 9 and dimethylamine. Flash chromatography eluent (DCM-MeOH, 5:5). Orange solid (yield: 40\%); $\mathrm{mp}=222-224{ }^{\circ} \mathrm{C} . \mathrm{IR}\left(\mathrm{cm}^{-1}\right) v_{\max } 3270,3154,3061$, 2923, 1634, 1584, 1519, 1492, 1410, 1346, 1291, 1226, 1201, 1152, 1116, 1049, 964, 881, 863, 831; ${ }^{19} \mathrm{~F}-\mathrm{NMR}\left(\mathrm{MeOD}-d_{4}\right) \delta-121.6 ;{ }^{1} \mathrm{H}-\mathrm{NMR}\left(\mathrm{MeOD}-d_{4}\right) \delta 8.18(\mathrm{~d}, 1 \mathrm{H}, J=9.0 \mathrm{~Hz}), 7.87(\mathrm{~s}, 1 \mathrm{H}), 7.53(\mathrm{~d}$, $1 \mathrm{H}, J=9.0 \mathrm{~Hz}), 7.28-7.19(\mathrm{~m}, 2 \mathrm{H}), 7.12(\mathrm{t}, 1 \mathrm{H}, J=9.0 \mathrm{~Hz}), 3.11(\mathrm{~s}, 6 \mathrm{H})$; HRMS calcd for $\mathrm{C}_{18} \mathrm{H}_{15} \mathrm{~N}_{6} \mathrm{SBrF}$ $[\mathrm{M}+\mathrm{H}]^{+}:$445.0246, found 445.0264.

9-(3-Chloro-4-fluorophenylamino)-N-(2-morpholinoethyl)thiazolo[5,4-f]quinazoline-2-carboximidamide (10a). Prepared from carbonitrile 10 and $N$-aminoethylmorpholine. Flash chromatography eluent (DCM-MeOH, 5:5). Yellow solid (yield: 71\%); $\mathrm{mp}=158-160{ }^{\circ} \mathrm{C} . \mathrm{IR}\left(\mathrm{cm}^{-1}\right) v_{\max } 2956,2816,1797$, 1614, 1561, 1485, 1256, 1199, 1113, 1069, 966, 916, 816; ${ }^{19} \mathrm{~F}-\mathrm{NMR}$ (DMSO-d6) $\delta-119.1$; ${ }^{1} \mathrm{H}-\mathrm{NMR}$ $\left(\mathrm{DMSO}-d_{6}\right) \delta 8.87(\mathrm{~s}, 1 \mathrm{H}, \mathrm{NH}), 8.43(\mathrm{~d}, 1 \mathrm{H}, J=7.2 \mathrm{~Hz}), 8.03(\mathrm{~m}, 1 \mathrm{H}), 7.90(\mathrm{~m}, 1 \mathrm{H}), 7.52(\mathrm{~m}, 1 \mathrm{H}), 7.39(\mathrm{~m}$, $1 \mathrm{H}), 7.18(\mathrm{~m}, 1 \mathrm{H}), 3.78-3.75(\mathrm{~m}, 4 \mathrm{H}), 3.52(\mathrm{~m}, 2 \mathrm{H}), 2.76-2.72(\mathrm{~m}, 2 \mathrm{H}), 2.60(\mathrm{~m}, 4 \mathrm{H})$; HRMS calcd for $\mathrm{C}_{22} \mathrm{H}_{22} \mathrm{~N}_{7} \mathrm{OSClF}[\mathrm{M}+\mathrm{H}]^{+}:$486.1279, found 486.1292 .

9-(3-Chloro-4-fluorophenylamino)-N-(2-(piperidin-1-yl)ethyl)thiazolo[5,4-f] quinazoline-2-carboximidamide (10b). Prepared from carbonitrile 10 and $N$-aminoethylpiperidine. Flash chromatography eluent (DCM-MeOH, 3:7). Orange solid (yield: 82\%); $\mathrm{mp}=146-148{ }^{\circ} \mathrm{C}$. IR $\left(\mathrm{cm}^{-1}\right) v_{\max } 2928,2361$, 1572, 1483, 1380, 1255, 1201, 1121, 1086, 1051, 964, 879, 818; ${ }^{19} \mathrm{~F}-\mathrm{NMR}\left(\mathrm{CDCl}_{3}\right) \delta-123.8 ;{ }^{1} \mathrm{H}-\mathrm{NMR}$ $\left(\mathrm{CDCl}_{3}\right) \delta 8.62(\mathrm{~s}, 1 \mathrm{H}), 8.35(\mathrm{~d}, 1 \mathrm{H}, J=9.0 \mathrm{~Hz}), 7.90(\mathrm{~d}, 1 \mathrm{H}, J=9.0 \mathrm{~Hz}), 7.70(\mathrm{~m}, 1 \mathrm{H}), 7.32(\mathrm{~m}, 1 \mathrm{H})$, $7.12(\mathrm{t}, 1 \mathrm{H}, J=9.0 \mathrm{~Hz}), 3.50(\mathrm{~m}, 2 \mathrm{H}), 2.63(\mathrm{t}, 2 \mathrm{H}, J=5.7 \mathrm{~Hz}), 2.49(\mathrm{~m}, 4 \mathrm{H}), 1.63-1.58(\mathrm{~m}, 4 \mathrm{H}), 1.48(\mathrm{~m}$, $2 \mathrm{H})$; HRMS calcd for $\mathrm{C}_{23} \mathrm{H}_{24} \mathrm{~N}_{7} \mathrm{SClF}[\mathrm{M}+\mathrm{H}]^{+}: 484.1486$, found 484.1501 .

9-(3-Chloro-4-fluorophenylamino)-N-(2-(pyrrolidin-1-yl)ethyl)thiazolo[5,4-f]quinazoline-2-carboximidamide (10c). Prepared from carbonitrile 10 and $N$-aminoethylpyrrolidine. Flash chromatography eluent (DCM-MeOH, 5:5). Orange solid (yield: 34\%); $\mathrm{mp}=166-168{ }^{\circ} \mathrm{C}$. IR $\left(\mathrm{cm}^{-1}\right) v_{\max } 3381,3146$, 2965, 2803, 1641, 1617, 1562, 1486, 1383, 1341, 1253, 1200, 1127, 1050, 965, 876, 816; ${ }^{19} \mathrm{~F}-\mathrm{NMR}$ $\left(\mathrm{MeOD}-d_{4}\right) \delta-125.6 ;{ }^{1} \mathrm{H}-\mathrm{NMR}\left(\mathrm{MeOD}-d_{4}\right) \delta 8.22(\mathrm{~d}, 1 \mathrm{H}, J=9.0 \mathrm{~Hz}), 7.95(\mathrm{~s}, 1 \mathrm{H}), 7.59(\mathrm{~d}, 1 \mathrm{H}, J=9.0 \mathrm{~Hz})$, $7.31(\mathrm{~m}, 1 \mathrm{H}), 7.18(\mathrm{t}, 1 \mathrm{H}, J=9.0 \mathrm{~Hz}), 7.15-7.12(\mathrm{~m}, 1 \mathrm{H}), 3.45(\mathrm{~m}, 2 \mathrm{H}), 2.85(\mathrm{~m}, 2 \mathrm{H}), 2.67(\mathrm{~m}, 4 \mathrm{H})$, $1.83(\mathrm{~m}, 4 \mathrm{H})$; HRMS calcd for $\mathrm{C}_{22} \mathrm{H}_{22} \mathrm{~N}_{7} \mathrm{SClF}[\mathrm{M}+\mathrm{H}]^{+}: 470.1330$, found 470.1340 .

9-(3-Chloro-4-fluorophenylamino)-N-(2-(dimethylamino)ethyl)thiazolo[5,4-f]quinazoline-2-carboximidamide (10d). Prepared from carbonitrile 10 and 2-dimethylaminoethylamine. Flash chromatography eluent (DCM-MeOH, 5:5). Pale yellow solid (yield: 50\%); $\mathrm{mp}=172-174{ }^{\circ} \mathrm{C}$. IR $\left(\mathrm{cm}^{-1}\right) v_{\max } 3224,3038$, 2950, 2861, 2824, 2773, 1618, 1560, 1488, 1386, 1323, 1254, 1195, 1127, 1086, 1052, 967, 816; ${ }^{19} \mathrm{~F}-\mathrm{NMR}\left(\mathrm{MeOD}-d_{4}\right) \delta-125.5$; ${ }^{1} \mathrm{H}-\mathrm{NMR}\left(\mathrm{MeOD}-d_{4}\right) \delta 8.34(\mathrm{~d}, 1 \mathrm{H}, J=9.0 \mathrm{~Hz}), 7.93(\mathrm{~s}, 1 \mathrm{H}), 7.67(\mathrm{~d}$, $1 \mathrm{H}, J=9.0 \mathrm{~Hz}), 7.29(\mathrm{~m}, 1 \mathrm{H}), 7.18(\mathrm{t}, 1 \mathrm{H}, J=9.0 \mathrm{~Hz}), 7.10-7.06(\mathrm{~m}, 1 \mathrm{H}), 3.64(\mathrm{t}, 2 \mathrm{H}, J=6.0 \mathrm{~Hz}), 3.27$ $(\mathrm{t}, 2 \mathrm{H}, J=6.0 \mathrm{~Hz}), 2.80(\mathrm{~s}, 6 \mathrm{H})$; HRMS calcd for $\mathrm{C}_{20} \mathrm{H}_{20} \mathrm{~N}_{7} \mathrm{SClF}[\mathrm{M}+\mathrm{H}]^{+}:$444.1173, found 444.1155. 
9-(3-Chloro-4-fluorophenylamino)-N-(2-(diethylamino)ethyl)thiazolo[5,4-f]quinazoline-2-carboximidamide (10e). Prepared from carbonitrile 10 and diethylethylenediamine. Flash chromatography eluent (DCM-MeOH, 5:5). Orange solid (yield: 50\%); $\mathrm{mp}=140-142{ }^{\circ} \mathrm{C}$. IR $\left(\mathrm{cm}^{-1}\right) v_{\max } 3295,2969$, $2812,1671,1618,1560,1489,1386,1346,1254,1196,1127,1052,966,817 ;{ }^{19} \mathrm{~F}-\mathrm{NMR}\left(\mathrm{MeOD}-d_{4}\right) \delta$ -125.3; ${ }^{1} \mathrm{H}-\mathrm{NMR}\left(\mathrm{MeOD}-d_{4}\right) \delta 8.29(\mathrm{~d}, 1 \mathrm{H}, J=9.0 \mathrm{~Hz}), 7.94(\mathrm{~s}, 1 \mathrm{H}), 7.63(\mathrm{~d}, 1 \mathrm{H}, J=9.0 \mathrm{~Hz})$, 7.29-7.20 (m, 2H), 7.09 (m, 1H), 3.60-3.56 (m, 2H), 2.90-2.83 (m, 2H), 2.77-2.74 (m, 4H), 1.17-1.06 (m, 6H); HRMS calcd for $\mathrm{C}_{22} \mathrm{H}_{24} \mathrm{~N}_{7} \mathrm{SClF}[\mathrm{M}+\mathrm{H}]^{+}: 472.1486$, found 472.1502 .

N-Benzyl-9-(3-chloro-4-fluorophenylamino)thiazolo[5,4-f]quinazoline-2-carboximidamide (10f). Prepared from carbonitrile 10 and benzylamine. Flash chromatography eluent (DCM-EtOAc, 2:8). Yellow solid (yield: $69 \%) ; \mathrm{mp}=230-232^{\circ} \mathrm{C} . \mathrm{IR}\left(\mathrm{cm}^{-1}\right) v_{\max } 3057,1725,1639,1490,1377,1341,1252,1202,1151$, 1121, 1086, 1050, 965, 818; ${ }^{19} \mathrm{~F}-\mathrm{NMR}\left(282 \mathrm{MHz}, \mathrm{MeOD}-d_{4}\right) \delta-125.3 ;{ }^{1} \mathrm{H}-\mathrm{NMR}\left(300 \mathrm{MHz}, \mathrm{MeOD}-d_{4}\right)$ $\delta 8.29(\mathrm{~d}, 1 \mathrm{H}, J=9.0 \mathrm{~Hz}), 7.94(\mathrm{~s}, 1 \mathrm{H}), 7.63(\mathrm{~d}, 1 \mathrm{H}, J=9.0 \mathrm{~Hz}), 7.43(\mathrm{~m}, 2 \mathrm{H}), 7.35-7.17(\mathrm{~m}, 5 \mathrm{H}), 7.10$ $(\mathrm{m}, 1 \mathrm{H}), 4.53(\mathrm{~s}, 2 \mathrm{H})$; HRMS calcd for $\mathrm{C}_{23} \mathrm{H}_{17} \mathrm{~N}_{6} \mathrm{SClF}[\mathrm{M}+\mathrm{H}]^{+}$: 463.0908, found 463.0916.

9-(3-Chloro-4-fluorophenylamino)-N,N-dimethylthiazolo[5,4-f]quinazoline-2-carboximidamide (10g). Prepared from carbonitrile 10 and dimethylamine. Flash chromatography eluent (DCM-MeOH, 5:5). Yellow solid (yield: $43 \%$ ); $\mathrm{mp}>260^{\circ} \mathrm{C}$. IR $(\mathrm{KBr}) v_{\max } / \mathrm{cm}^{-1} 3411,3051,1663,1623,1559,1488,1383$, 1254, 1202, 1150, 1051, 966, 819; ${ }^{19} \mathrm{~F}-\mathrm{NMR}\left(\mathrm{MeOD}-d_{4}\right) \delta-125.9 ;{ }^{1} \mathrm{H}-\mathrm{NMR}\left(\mathrm{MeOD}-d_{4}\right) \delta 8.45(\mathrm{~d}, 1 \mathrm{H}$, $J=9.0 \mathrm{~Hz}), 7.98(\mathrm{~s}, 1 \mathrm{H}), 7.75(\mathrm{~d}, 1 \mathrm{H}, J=9.0 \mathrm{~Hz}), 7.30-7.21(\mathrm{~m}, 2 \mathrm{H}), 7.12(\mathrm{t}, 1 \mathrm{H}, J=9.0 \mathrm{~Hz}), 3.39$ (s, $6 \mathrm{H})$; HRMS calcd for $\mathrm{C}_{18} \mathrm{H}_{15} \mathrm{~N}_{6} \mathrm{SClF}[\mathrm{M}+\mathrm{H}]^{+}: 401.0751$, found 401.0742 .

\subsubsection{Synthesis of Amides $\mathbf{7 h}-\mathbf{1 0 h}$}

General procedure: a stirred mixture of carbonitriles $\mathbf{7 - 1 0}(0.13 \mathrm{mmol})$ and $\mathrm{NaOH}(2.5 \mathrm{~N}$ sol., $50 \mu \mathrm{L})$ in butanol $(2.5 \mathrm{~mL})$ was heated under microwaves at $117^{\circ} \mathrm{C}(600 \mathrm{~W})$ for $30 \mathrm{~min}$. The solvent was removed in vacuo and the crude residue purified by flash chromatography (DCM-EtOAc, 5:5) to afford amides $\mathbf{7 h}-\mathbf{1 0 h}$.

9-(4-Methoxyphenylamino)thiazolo[5,4-f]quinazoline-2-carboxamide (7h). Orange solid (yield: 98\%); $\mathrm{mp}=213^{\circ} \mathrm{C} . \mathrm{IR}\left(\mathrm{cm}^{-1}\right) v_{\max } 3409,1691,1638,1600,1572,1509,1431,1380,1349,1325,1301,1237$, 1177, 1123, 1085, 1032, 964, 835, 814; ${ }^{1} \mathrm{H}-\mathrm{NMR}$ (DMSO-d6) $\delta 8.37$ (s, 1H), 8.24 (d, 1H, $J=9.0 \mathrm{~Hz}$ ), 8.06 (s, 1H), 7.92 (s, 1H), 7.61 (d, 1H, $J=9.0 \mathrm{~Hz}), 7.31$ (d, 2H, $J=9.0 \mathrm{~Hz}), 6.89$ (d, 2H, $J=9.0 \mathrm{~Hz})$, $3.74(\mathrm{~s}, 3 \mathrm{H})$; HRMS calcd for $\mathrm{C}_{17} \mathrm{H}_{14} \mathrm{~N}_{5} \mathrm{O}_{2} \mathrm{~S}[\mathrm{M}+\mathrm{H}]^{+}$: 352.0868 , found 352.0879 .

9-(Benzo[d][1,3]dioxol-5-ylamino)thiazolo[5,4-f]quinazoline-2-carboxamide $\mathbf{( 8 h ) . ~ Y e l l o w ~ s o l i d ~ ( y i e l d : ~}$ $31 \%) ; \mathrm{mp}>260{ }^{\circ} \mathrm{C}$. IR (KBr) $v_{\max } / \mathrm{cm}^{-1} 3291,2915,1648,1576,1532,1497,1476,1376,1351,1323$, 1272, 1191, 1104, 1035, 965, 923, 830, 815; ${ }^{1} \mathrm{H}-\mathrm{NMR}$ (DMSO-d6) $\delta$ 8.05-7.98 (m, 2H), 7.49 (d, 1H, $J=2 \mathrm{~Hz}), 7.37-7.31(\mathrm{~m}, 1 \mathrm{H}), 6.96\left(\mathrm{dd}, 1 \mathrm{H}, J_{1}=2 \mathrm{~Hz}, J_{2}=9 \mathrm{~Hz}\right), 6.73\left(\mathrm{dd}, 1 \mathrm{H}, J_{1}=2 \mathrm{~Hz}, J_{2}=9 \mathrm{~Hz}\right)$, 5.88 (s, 2H); HRMS calcd for $\mathrm{C}_{17} \mathrm{H}_{12} \mathrm{~N}_{5} \mathrm{O}_{3} \mathrm{~S}[\mathrm{M}+\mathrm{H}]^{+}: 366.0661$, found 366.0658 .

9-(4-Bromo-2-fluorophenylamino)thiazolo[5,4-f]quinazoline-2-carboxamide (9h). Yellow solid (yield: $71 \%) ; \mathrm{mp}>260{ }^{\circ} \mathrm{C}$. IR (KBr) $v_{\max } / \mathrm{cm}^{-1} 1682,1645,1615,1575,1557,1486,1347,1254,1200,1158$, $1118,1074,993,967,941,865,819 ;{ }^{19} \mathrm{~F}-\mathrm{NMR}\left(\mathrm{DMSO}-d_{6}\right) \delta-120.5 ;{ }^{1} \mathrm{H}-\mathrm{NMR}\left(\mathrm{DMSO}-d_{6}\right) \delta 8.47(\mathrm{~s}$, 
$1 \mathrm{H}), 8.41(\mathrm{~d}, 1 \mathrm{H}, J=9.0 \mathrm{~Hz}), 8.39(\mathrm{~s}, 1 \mathrm{H}), 8.14(\mathrm{~s}, 1 \mathrm{H}), 8.03(\mathrm{~d}, 1 \mathrm{H}, J=9.0 \mathrm{~Hz}), 7.53(\mathrm{~m}, 1 \mathrm{H}), 7.36(\mathrm{~m}$, $1 \mathrm{H}), 7.21(\mathrm{t}, 1 \mathrm{H}, J=9.0 \mathrm{~Hz})$; HRMS calcd for $\mathrm{C}_{16} \mathrm{H}_{10} \mathrm{~N}_{5} \mathrm{OSBrF}[\mathrm{M}+\mathrm{H}]^{+}:$417.9769, found 417.9769.

9-(3-Chloro-4-fluorophenylamino)thiazolo[5,4-f]quinazoline-2-carboxamide (10h). Orange solid (yield: 98\%); $\mathrm{mp}>260{ }^{\circ} \mathrm{C}$. IR (KBr) $v_{\max } / \mathrm{cm}^{-1} 3453,1684,1624,1601,1576,1534,1506,1487,1376$, 1348, 1282, 1260, 1209, 1124, 1085, 1057, 993, 969, 825, 810; ${ }^{19} \mathrm{~F}-\mathrm{NMR}$ (DMSO-d6) $\delta-129.1$; ${ }^{1} \mathrm{H}-\mathrm{NMR}\left(\mathrm{DMSO}-d_{6}\right) \delta 8.26-8.21(\mathrm{~m}, 2 \mathrm{H}), 8.12(\mathrm{~d}, 1 \mathrm{H}, J=9.0 \mathrm{~Hz}), 8.02-7.99(\mathrm{~m}, 1 \mathrm{H}), 7.80(\mathrm{~s}, 1 \mathrm{H})$, $7.53(\mathrm{~d}, 1 \mathrm{H}, J=9.0 \mathrm{~Hz}), 7.47(\mathrm{~m}, 1 \mathrm{H}), 7.18(\mathrm{t}, 1 \mathrm{H}, J=9.0 \mathrm{~Hz})$; HRMS calcd for $\mathrm{C}_{16} \mathrm{H}_{10} \mathrm{~N}_{5} \mathrm{OSClF}$ $[\mathrm{M}+\mathrm{H}]^{+}: 374.0279$, found 374.0280 .

\subsubsection{Synthesis of Methylimidates $\mathbf{7} \mathbf{i}-\mathbf{- 1 0} \mathbf{i}$}

General procedure: a stirred mixture of carbonitriles 7-10 $(0.13 \mathrm{mmol})$ and $\mathrm{NaOCH}_{3}(0.5 \mathrm{M}$ sol. in $\mathrm{MeOH}, 130 \mu \mathrm{L})$ in methanol $(4 \mathrm{~mL})$ was heated under microwaves at $65^{\circ} \mathrm{C}(600 \mathrm{~W})$ for $30 \mathrm{~min}$. The solvent was removed in vacuo and the crude residue purified by flash chromatography (DCM-EtOAc) to afford imidates $\mathbf{7 i - 1 0 i}$.

Methyl 9-(4-methoxyphenylamino)thiazolo[5,4-f]quinazoline-2-carbimidate (7i). Purified by flash chromatography (DCM-EtOAc, 5:5) as orange solid (yield: 82\%); mp = 240-242 ${ }^{\circ} \mathrm{C}$. IR $\left(\mathrm{cm}^{-1}\right)$; $v_{\max }$ 2833, 2354, 1644, 1614, 1567, 1504, 1439, 1397, 1373, 1349, 1325, 1286, 1240, 1215, 1181, 1155, 1104, 1069, 1033, 965, 935, 859, 832, 814; ${ }^{1} \mathrm{H}-\mathrm{NMR}\left(\mathrm{MeOD}-d_{4}\right) \delta 8.09$ (d, 1H, $J=9.0 \mathrm{~Hz}$ ), 7.93 (s, $1 \mathrm{H}), 7.50(\mathrm{~d}, 1 \mathrm{H}, J=9.0 \mathrm{~Hz}), 7.14(\mathrm{~d}, 2 \mathrm{H}, J=9.0 \mathrm{~Hz}), 6.82(\mathrm{~d}, 2 \mathrm{H}, J=9.0 \mathrm{~Hz}), 3.98(\mathrm{~s}, 3 \mathrm{H}), 3.74$ (s, $3 \mathrm{H})$; HRMS calcd for $\mathrm{C}_{18} \mathrm{H}_{16} \mathrm{~N}_{5} \mathrm{O}_{2} \mathrm{~S}[\mathrm{M}+\mathrm{H}]^{+}: 366.1025$, found 366.1034 .

Methyl 9-(benzo[d][1,3]dioxol-5-ylamino)thiazolo[5,4-f]quinazoline-2-carbimidate (8i). Purified by flash chromatography (DCM-EtOAc, 5:5) as yellow solid (yield: 92\%); mp = 230-232 ${ }^{\circ} \mathrm{C} . \mathrm{IR}\left(\mathrm{cm}^{-1}\right)$ $v_{\max } / 3287,2902,1648,1617,1575,1528,1499,1483,1452,1432,1385,1322,1272,1196,1125,1043$, 936, 885, 834, 817; ${ }^{1} \mathrm{H}-\mathrm{NMR}$ (DMSO-d6) $\delta 8.36(\mathrm{~d}, 1 \mathrm{H}, J=9 \mathrm{~Hz}), 7.96(\mathrm{~s}, 1 \mathrm{H}), 7.71(\mathrm{~d}, 1 \mathrm{H}, J=9 \mathrm{~Hz})$, $6.87(\mathrm{~d}, 1 \mathrm{H}, J=8 \mathrm{~Hz}), 6.74(\mathrm{~m}, 1 \mathrm{H}), 6.63(\mathrm{~d}, 1 \mathrm{H}, J=8 \mathrm{~Hz}), 5.96(\mathrm{~s}, 2 \mathrm{H}), 4.05(\mathrm{~s}, 3 \mathrm{H})$; HRMS calcd for $\mathrm{C}_{18} \mathrm{H}_{14} \mathrm{~N}_{5} \mathrm{O}_{3} \mathrm{~S}[\mathrm{M}+\mathrm{H}]^{+}: 380.0817$, found 380.0805 .

Methyl 9-(4-bromo-2-fluorophenylamino)thiazolo[5,4-f]quinazoline-2-carbimidate (9i). Purified by flash chromatography eluent (DCM-EtOAc, 2:8) as pale yellow solid (yield: 94\%); mp $>260{ }^{\circ} \mathrm{C}$. IR $\left(\mathrm{cm}^{-1}\right) v_{\max } 2950,1638,1617,1595,1555,1507,1479,1434,1398,1352,1325,1288,1224,1197,1159$, $1115,1070,988,965,942,882,818 ;{ }^{19} \mathrm{~F}-\mathrm{NMR}\left(\mathrm{DMSO}-d_{6}\right) \delta-119.8 ;{ }^{1} \mathrm{H}-\mathrm{NMR}$ (DMSO- $\left.d_{6}\right) \delta 8.46(\mathrm{~d}, 1 \mathrm{H}$, $J=9.0 \mathrm{~Hz}), 8.02(\mathrm{~s}, 1 \mathrm{H}), 7.69(\mathrm{~d}, 1 \mathrm{H}, J=9.0 \mathrm{~Hz}), 7.53(\mathrm{~m}, 1 \mathrm{H}), 7.35(\mathrm{~m}, 1 \mathrm{H}), 7.20(\mathrm{t}, 1 \mathrm{H}, J=9.0 \mathrm{~Hz})$, 3.94 (s, 3H); HRMS calcd for $\mathrm{C}_{17} \mathrm{H}_{12} \mathrm{~N}_{5} \mathrm{OSBrF}[\mathrm{M}+\mathrm{H}]^{+}: 431.9930$, found 431.9937 .

Methyl 9-(3-chloro-4-fluorophenylamino)thiazolo[5,4-f]quinazoline-2-carbimidate (10i). Purified by flash chromatography (DCM-EtOAc, 5:5) as orange solid (yield: 98\%); mp = 210-212 ${ }^{\circ} \mathrm{C}$. IR $(\mathrm{KBr})$ $v_{\max } / \mathrm{cm}^{-1} 1642,1559,1479,1352,1260,1201,1156,1073,942,817 ;{ }^{19} \mathrm{~F}-\mathrm{NMR}$ (DMSO-d 6 ) $\delta-126.9$; ${ }^{1} \mathrm{H}-\mathrm{NMR}\left(\mathrm{DMSO}-d_{6}\right) \delta 8.29(\mathrm{~d}, 1 \mathrm{H}, J=9.0 \mathrm{~Hz}), 8.18(\mathrm{~s}, 1 \mathrm{H}), 7.73(\mathrm{~m}, 1 \mathrm{H}), 7.61(\mathrm{~d}, 1 \mathrm{H}, J=9.0 \mathrm{~Hz})$, $7.30(\mathrm{~m}, 1 \mathrm{H}), 7.27(\mathrm{t}, 1 \mathrm{H}, J=9.0 \mathrm{~Hz}), 3.95(\mathrm{~s}, 3 \mathrm{H})$; HRMS calcd for $\mathrm{C}_{17} \mathrm{H}_{12} \mathrm{~N}_{5} \mathrm{OSClF}[\mathrm{M}+\mathrm{H}]^{+}: 388.0435$, found 388.0447 . 


\subsection{In Vitro Kinase Preparation and Assays [19]}

\subsubsection{Buffers}

Buffer A: $\mathrm{MgCl}_{2}(10 \mathrm{mM}), 1 \mathrm{mM}$ ethylene glycol-bis(2-aminoethylether)- $N, N, N^{\prime}, N^{\prime}$-tetraacetic acid (EGTA), $1 \mathrm{mM}$ dithiothreitol (DTT), $25 \mathrm{mM}$ Tris- $\mathrm{HCl} \mathrm{pH}$ 7.5, $50 \mu \mathrm{g}$ heparin $/ \mathrm{mL}$.

Buffer B: $\beta$-Glycerophosphate $\quad(60 \mathrm{mM}), \quad 30 \quad \mathrm{mM} \quad p$-nitrophenylphosphate, $25 \mathrm{mM}$ 3-( $N$-morpholino)propanesulfonic acid (Mops) (pH 7.2), $5 \mathrm{mM} \mathrm{EGTA,} 15 \mathrm{mM} \mathrm{MgCl}$, $1 \mathrm{mM}$ DTT, $0.1 \mathrm{mM}$ sodium vanadate.

\subsubsection{Kinase Preparations and Assays}

Kinase activities were assayed in triplicates in buffer $\mathrm{A}$ or $\mathrm{B}$, for $30 \mathrm{~min}$. at $30^{\circ} \mathrm{C}$, at a final adenosine triphosphate (ATP) concentration of $15 \mu \mathrm{M}$. Blank values were subtracted and activities expressed in $\%$ of the maximal activity, i.e., in the absence of inhibitors. Controls were performed with appropriate dilutions of dimethylsulfoxide (DMSO). IC50 values were calculated from dose-response curves established by Sigma-Plots. The GSK-3, CK1, DYRK1A and CLK1 peptide substrates were obtained from Proteogenix (Oberhausbergen, France).

$C D K 5 / p 25$. (Human, recombinant) was prepared as previously described [20,21]. Its kinase activity was assayed in buffer A, with $1 \mathrm{mg}$ of histone $\mathrm{H} 1 / \mathrm{mL}$, in the presence of $15 \mu \mathrm{M}\left[\gamma^{3}{ }^{33} \mathrm{P}\right]$ ATP $(3000 \mathrm{Ci} / \mathrm{mmol} ; 10 \mathrm{mCi} / \mathrm{mL})$ in a final volume of $30 \mu \mathrm{L}$. After $30 \mathrm{~min}$ incubation at $30^{\circ} \mathrm{C}, 25 \mu \mathrm{L}$ aliquots of supernatant were spotted onto sheets of Whatman P81 phosphocellulose paper, and $20 \mathrm{~s}$ later, the filters were washed eight times (for at least $5 \mathrm{~min}$ each time) in a solution of $10 \mathrm{~mL}$ phosphoric acid/L of water. The wet filters were counted in the presence of $1 \mathrm{~mL}$ ACS (Amersham) scintillation fluid.

$G S K-3 \alpha / \beta$. (Porcine brain, native) was assayed as described for CDK5/p25, but in buffer A and using a GSK-3 specific substrate (GS-1: YRRAAVPPSPSLSRHSSPHQpSEDEEE) (pS stands for phosphorylated serine) [22].

$C K 1 \delta / \varepsilon$. (Porcine brain, native) was assayed as described for CDK5/p25, but using the CK1-specific peptide substrate RRKHAAIGpSAYSITA [23].

DYRK1A. (Rat, recombinant, expressed in E. coli as a glutathione transferase (GST) fusion protein) was purified by affinity chromatography on glutathione-agarose and assayed, as described for CDK5/p25 using Woodtide (KKISGRLSPIMTEQ) (1.5 $\mu \mathrm{g}$ /assay) as a substrate.

\section{Conclusions}

The convenient synthesis of a forty molecule library of novel 6,6,5-tricyclic thiazolo[5,4- $f$-quinazolines was realized under microwave irradiation associating Dimroth rearrangement for construction the pyrimidine part and 4,5-dichloro-1,2,3,-dithiazolium chloride (Appel salt) chemistry for introducing the thiazole ring to its quinazoline partner. Our work allowed to prepare in an efficient and reproducible multistep synthesis a novel 6-aminobenzo[ $d]$ thiazole-2,7-dicarbonitrile (16) which can be considered as a very powerful molecular platform for the synthesis of various bioactive derivatives. On chemical and practical aspects this article is a further example illustrating how microwave heating can be a very powerful tool for medicinal chemistry. 
The inhibitory potency of the final products against a panel of four kinases was evaluated. In view of the results of this preliminary study, we consider that the thiazolo[5,4-f]quinazoline derivatives (series 7-10) constitute a promising source of inspiration for the synthesis of novel bioactive molecules. Novel synthetic transformations will be explored and factors governing the dual activity of the compounds toward DYRK1A and GSK3 will be further investigated.

\section{Acknowledgments}

Financial support from the MESR (Ministère de l'Enseignement Supérieur et de la Recherche) is gratefully acknowledged for the doctoral fellowships to A.F. and D.H. We thank the LABEX SynOrg (ANR-11-LABX-0029) and AI-Chem Channel program for financial support. We also acknowledge Anton Paar GmbH (Graz, Austria) for provision of single-mode microwave reactors (Monowave 300) and Milestone S.r.l. (Italy) for technical support. LM acknowledges the support of the European Union 7th Framework Program Knowledge-Based Bio-economy (FP7-KBBE)- BlueGenics 2012 grant.

\section{Author Contributions}

T.B. and B.L. conceived the project. T.B., A.F. and D.H. designed the experiments and executed the chemical synthesis. A.-S.C., L.D., N.L. and L.M. designed and performed the biological experiments. T.B. wrote the paper. All authors discussed the results and commented on the manuscript.

\section{Conflicts of Interest}

The authors declare no conflict of interest.

\section{References and Notes}

1. Martin, L.; Latypova, X.; Wilson, C.M.; Magnaudeix, A.; Perrin, M.-L.; Terro, F. Tau protein kinases: Involvement in Alzheimer's disease. Ageing Res. Rev. 2013, 12, 289-309.

2. Flajolet, M.; He, G.; Heiman, M.; Lin, A.; Nairn, A.C.; Greengard, P. Regulation of Alzheimer's disease amyloid- $\beta$ formation by casein kinase I. Proc. Nat. Acad. Sci. USA 2007, 104, 4159-4164.

3. Weinmann, H.; Metternich, R. Drug discovery process for kinase Inhibitors. ChemBioChem 2005, $6,455-459$; this paper is the editorial of a special issue "Kinases in drug discovery" ChemBioChem 2005, 6, 453-574.

4. Loidreau, Y.; Marchand, P.; Dubouilh-Benard, C.; Nourrisson, M.-R.; Duflos, M.; Loaëc, N.; Meijer, L.; Besson, T. Synthesis and biological evaluation of $N$-aryl-7-methoxybenzo[b]furo[3,2$d]$ pyrimidin-4-amines and their $N$-arylbenzo[b]thieno[3,2- $d]$ pyrimidin-4-amine analogues as dual inhibitors of CLK1 and DYRK1A kinases. Eur. J. Med. Chem. 2013, 59, 283-295.

5. Loidreau, Y.; Marchand, P.; Dubouilh-Benard, C.; Nourrisson, M.-R.; Duflos, M.; Lozach, O.; Loaëc, N.; Meijer, L.; Besson, T. Synthesis and biological evaluation of $\mathrm{N}$-arylbenzo[b]thieno[3,2- $d]$ pyrimidin-4-amines and their pyrido and pyrazino analogues as Ser/Thr kinase inhibitors. Eur. J. Med. Chem. 2012, 58, 171-183. 
6. Foucourt, A.; Dubouilh-Benard, C.; Chosson, E.; Corbière, C.; Buquet, C.; Iannelli, M.; Leblond, B.; Marsais, F.; Besson, T. Microwave-accelerated Dimroth rearrangement for the synthesis of 4-anilino-6-nitroquinazolines. Application to an efficient synthesis of a microtubule destabilizing agent. Tetrahedron 2010, 66, 4495-4502.

7. Logé, C.; Testard, A.; Thiéry, V.; Lozach, O.; Blairvacq, M.; Robert, J.-M.; Meijer, L.; Besson, T. Novel 9-oxo-thiazolo[5,4-f]quinazoline-2-carbonitrile derivatives as dual cyclin-dependent kinase 1 (CDK1)/glycogen synthase kinase-3 (GSK-3) inhibitors: synthesis, biological evaluation and molecular modeling studies. Eur. J. Med. Chem. 2008, 43, 1469-1477.

8. Testard, A.; Logé, C.; Léger, B.; Robert, J.-M.; Lozach, O.; Blairvacq, M.; Meijer, L.; Thiéry, V.; Besson, T. Thiazolo[5,4-f]quinazolin-9-ones, inhibitors of glycogen synthase kinase-3. Bioorg. Med. Chem. Lett. 2006, 16, 3419-3423.

9. Alexandre, F.R.; Berecibar, A.; Wrigglesworth, R.; Besson, T. Efficient synthesis of thiazoloquinazolinone derivatives. Tetrahedron Lett. 2003, 44, 4455-4458.

10. Besson, T.; Guillard, J.; Rees, C.W. Multistep Synthesis of Thiazoloquinazolines under Microwave Irradiation in Solution. Tetrahedron Lett. 2000, 41, 1027-1030.

11. For a complete review see: Harris, C.S.; Hennequin, L.; Morgentin, R.; Pasquet, G. Synthesis and functionnalization of 4-substituted quinazolines as kinases templates. In Targets in Heterocyclic Systems-Chemistry and Properties; Attanasi, O.A., Spinelli, D., Eds.; Italian Society of Chemistry: Roma, Italia, 2010; Volume 14, pp. 315-350.

12. Alexandre, F.R.; Domon, L.; Frère, S.; Testard, A.; Thiéry, V.; Besson, T. Microwaves in drug discovery and multi-step synthesis. Mol. Divers. 2003, 7, 273-280.

13. Guillon, R.; Pagniez, F.; Picot, C.; Hédou, D.; Tonnerre, A.; Chosson, E.; Duflos, M.; Besson, T.; Logé, C.; Le Pape, P. Discovery of a Novel Broad-spectrum Antifungal Agent, Derived from Albaconazole. ACS Med. Chem. Lett. 2013, 4, 288-292.

14. Hédou, D.; Guillon, R.; Lecointe, C.; Logé, C.; Chosson, E.; Besson, T. Novel synthesis of angular thiazolo[5,4-f] and [4,5-h]quinazolines, preparation of their linear thiazolo[4,5-g] and [5,4-g]quinazoline analogs. Tetrahedron 2013, 69, 3182-3191.

15. Deau, E.; Hédou, D.; Chosson, E.; Levacher, V.; Besson, T. Convenient one-pot synthesis of $N^{3}$-substituted pyrido[2,3-d]-, pyrido[3,4- $\left.d\right]$-, pyrido[4,3- $\left.d\right]$-pyrimidin-4(3H)-ones, and quinazolin-4(3H)-ones analogs. Tetrahedron Lett. 2013, 54, 3518-3521.

16. Besson, T.; Dozias, M.J.; Guillard, J.; Rees, C.W. New Route to 2-Cyanobenzothiazoles via N-Arylimino-1,2,3-dithiazoles. J. Chem. Soc. Perkin Trans. 1 1998, 3925-3926.

17. For recent example of this strategy for the synthesis of bioactive molecules see ref. [6].

18. Loidreau, Y.; Melissen, S.; Levacher, V.; Logé, C.; Graton, J.; Le Questel, J.Y.; Besson, T. Study of $N^{1}$-alkylation of indoles from the reaction of 2(or 3)-aminoindole-3-(or 2)carbonitriles with DMF-dialkylacetals. Org. Biomol. Chem. 2012, 20, 4916-4925.

19. Giraud, F.; Alves, G.; Debiton, E.; Nauton, L.; Théry, V.; Durieu, E.; Ferandin, Y.; Lozach, O.; Meijer, L.; Anizon, F.; et al. Synthesis, protein kinase inhibitory potencies, and in vitro antiproliferative activities of meridianin derivatives. J. Med. Chem. 2011, 54, 4474-4489.

20. Bach, S.; Knockaert, M.; Reinhardt, J.; Lozach, O.; Schmitt, S.; Baratte, B.; Koken, M.; Coburn, P.; Tang, L.; Jiang, T.; et al. Roscovitine targets, protein kinases and pyridoxal kinase. J. Biol. Chem. 2005, 280, 31208-31219. 
21. Bidd, J.A.; Snyder, G.L.; Greengard, P.; Biernat, J.; Wu, Y.-Z.; Mandelkow, E.-M.; Eisenbrand, G.; Meijer, L. Indirubins inhibit glycogen synthase kinase-3 $\beta$ and CDK5/P25, two protein kinases involved in abnormal tau phosphorylation in Alzheimer's Disease: A property common to most cyclin-dependent kinase inhibitors? J. Biol. Chem. 2001, 276, 251-260.

22. Primot, A.; Baratte, B.; Gompel, M.; Borgne, A.; Liabeuf, S.; Romette, J.L.; Jho, E.H.; Costantini, F.; Meijer, L. Purification of GSK-3 by affinity chromatography on immobilized axin. Protein Expr. Purif. 2000, 20, 394-404.

23. Reinhardt, J.; Ferandin, Y.; Meijer, L. Purification of CK1 by affinity chromatography on immobilised axin. Protein Expr. Purif. 2007, 54, 101-109.

24. Patel, K.; Gadewar, M.; Tripathi, R.; Prasad, S.K.; Patel, D.K. A review on medicinal importance, pharmacological activity and bioanalytical aspects of beta-carboline alkaloid "Harmine". Asian Pac. J. Trop. Biomed. 2012, 2, 660-664.

25. Debdab, M.; Carreaux, F.; Renault, S.; Soundararajan, M.; Fedorov, O.; Filippakopoulos, P.; Lozach, O.; Babault, L.; Tahtouh, T.; Baratte, B.; et al. Leucettines, a class of potent inhibitors of cdc2-like kinases and dual specificity, tyrosine phosphorylation regulated kinases derived from the marine sponge leucettamine B. Modulation of alternative pre-RNA splicing. J. Med. Chem. 2011, $54,4172-4186$.

26. Tahtouh, T.; Elkins, J.M.; Filippakopoulos, P.; Soundararajan, M.; Burgy, G.; Durieu, E.; Cochet, C.; Schmid, R.S.; Lo, D.C.; Delhommel, F.; et al. Selectivity, co-crystal structures and neuroprotective properties of Leucettines, a family of protein kinase inhibitors derived from the marine sponge alkaloid Leucettamine B. J. Med. Chem. 2012, 55, 9312-9330.

27. Frederick, R.; Bruyere, C.; Vancraeynest, C.; Reniers, J.; Meinguet, C.; Pochet, L.; Backlund, A.; Masereel, B.; Kiss, R.; Wouters, J. Novel Trisubstituted Harmine Derivatives with Original in Vitro Anticancer Activity. J. Med. Chem. 2012, 55, 6489-6501.

28. Armen Instrument. Available online: http://www.armen-instrument.com (accessed on 24 September 2014).

29. Leblond, B.; Casagrande, A.-S.; Desire, L.; Foucourt, A.; Besson, T. DYRK1 Inhibitors and Uses Thereof. U.S. Patent 20,140,275,064, 18 September 2014.

Sample Availability: Samples of the compounds are not available from the authors.

(C) 2014 by the authors; licensee MDPI, Basel, Switzerland. This article is an open access article distributed under the terms and conditions of the Creative Commons Attribution license (http://creativecommons.org/licenses/by/4.0/). 